\title{
WestVirginiaUniversity
}

THE RESEARCH REPOSITORY @ WVU

Graduate Theses, Dissertations, and Problem Reports

2017

\section{Growing Community Gardens in the Mountain State}

Mary Ryan

Follow this and additional works at: https://researchrepository.wvu.edu/etd

\section{Recommended Citation}

Ryan, Mary, "Growing Community Gardens in the Mountain State" (2017). Graduate Theses, Dissertations, and Problem Reports. 6547.

https://researchrepository.wvu.edu/etd/6547

This Thesis is protected by copyright and/or related rights. It has been brought to you by the The Research Repository @ WVU with permission from the rights-holder(s). You are free to use this Thesis in any way that is permitted by the copyright and related rights legislation that applies to your use. For other uses you must obtain permission from the rights-holder(s) directly, unless additional rights are indicated by a Creative Commons license in the record and/ or on the work itself. This Thesis has been accepted for inclusion in WVU Graduate Theses, Dissertations, and Problem Reports collection by an authorized administrator of The Research Repository @ WVU. For more information, please contact researchrepository@mail.wvu.edu. 


\title{
Growing Community Gardens in the Mountain State
}

\author{
Mary Ryan \\ Thesis submitted to the Eberly College of Arts and Sciences at \\ West Virginia University \\ in partial fulfillment of the requirements for the degree of \\ Master of Arts in Geography \\ Bradley Wilson, Ph.D., Chair \\ Cheryl Brown, Ph.D. \\ Jonathan Hall, Ph.D. \\ Department of Geology \& Geography
}

Morgantown, West Virginia

2017

Keywords: food sovereignty; food security; community gardening; West Virginia Copyright 2017 Mary Ryan 


\section{Abstract \\ Growing Community Gardens in the Mountain State \\ Mary Ryan}

Community gardening is being used to address food inequality as an alternative food network. Most literature looks at community gardening in urban contexts. Less is known about community gardening in rural areas. My research was able to address how community gardening contributes to food sovereignty in WV and how garden leaders help contribute to this access to food sovereignty. Through a survey of 19 community gardens across West Virginia I show the organization and use of these gardens. Through interviews with 11 of those gardens, I was able to learn about how garden leaders' frame their gardens' goals and importance to the community. In return these frames show how WV gardens view their movement in an apolitical way vs. the more political goals of the food sovereignty movement. On the other hand, the gardens are able to use food sovereignty to help the food security, food access, and health of their communities. 


\section{Table of Contents}

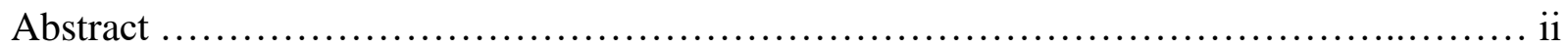

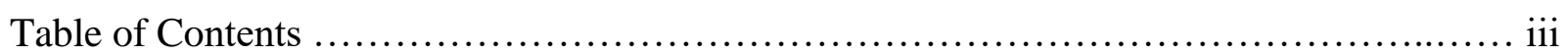

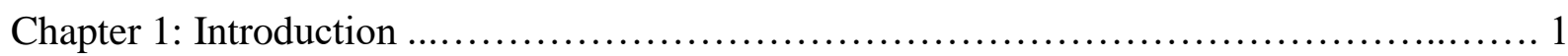

Chapter 2: Literature Review ................................................ 2

History of Gardening in the U.S. ........................................ 11

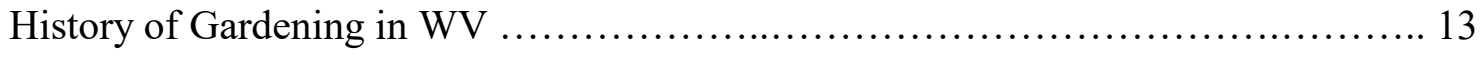

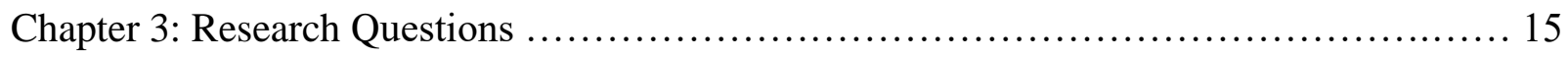

Chapter 4: Research Design .................................................. 16

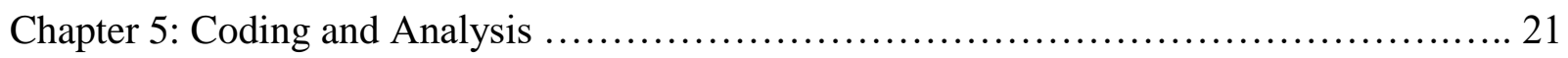

Chapter 6: Preliminary Research Findings ........................................... 22

Chapter 7: Research Findings: Participant Observations and Interviews ................. 30

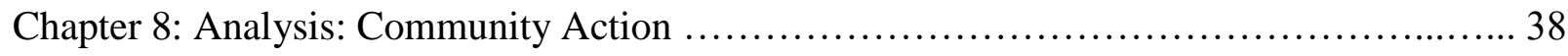

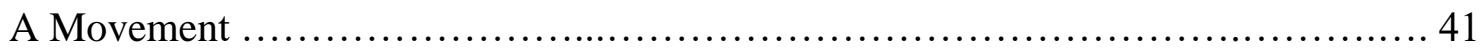

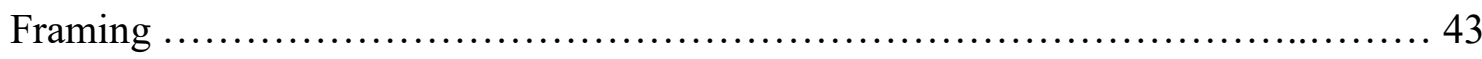

Political/Apolitical .................................................... 48

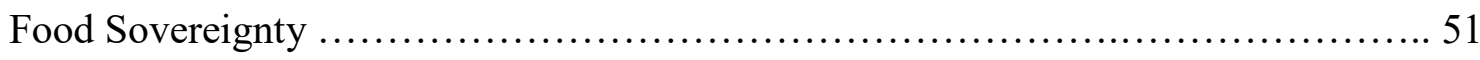

Chapter 9: Overview, Further Research, and Limitations ............................. 53

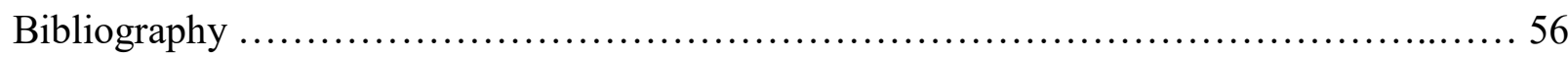

Appendix A: West Virginia Community Garden Survey............................... 59

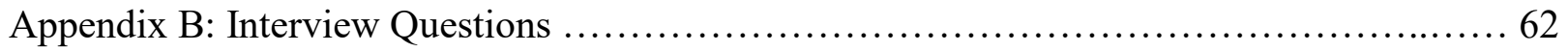




\section{Chapter 1: Introduction}

West Virginia has a poverty rate of $16.5 \%$, with $6.9 \%$ unemployed, and $24.2 \%$ living in food hardship, meaning that the household does not earn enough money to cover food costs at least once in a twelve-month period (WV FOODLINK 2016). On top of the large number of people who cannot afford food, are the people who are living in "food deserts" and do not have access to fresh healthy produce. Food deserts are areas where people do not have quick access to a supermarket where they can buy fresh food. People and families that earn a low income have the greatest number of barriers to face when it comes to accessing food (WV FOODLINK 2016). To address this crisis, alternative food outlets such as gardening and farmer's markets have started to grow in popularity within the state, but still only $2 \%$ of WV citizens shopped at a farmer's market or alternative food hub last year (WV FOODLINK 2016). Community gardens are rising up in several areas in West Virginia and they are giving communities the ability to have access to affordable healthy food. Community gardens are communal sites where people from the neighborhood can grow food, among other things, in an area designated for the activity.

Food sovereignty is a concept and global movement that was launched at the World Food Summit in 1996 (US Food Sovereignty Alliance 2016). It holds many goals behind its creation, but it mainly values the promotion of people's right to have access and control over the production, distribution, and consumption of their food (US Food Sovereignty Alliance 2016). There is a gap in the literature that does not show how food sovereignty is used in a North American rural context. The objective of my research is to examine West Virginia community gardening in terms of food sovereignty. My research will be able to address how community gardening can contribute to food sovereignty in West Virginia. Through interviews I aim to better understand how leaders of community gardens are running the gardens within the state, 
and if food sovereignty is a part of their vision for what the garden can provide. I will examine community gardens through qualitative methods, including surveying, interviewing, and participant observations.

\section{Chapter 2: Literature Review}

Growing concerns about community food security, food deserts, and the efforts of people who live in low-income communities to improve access to food, has played a central role in the geographic literature over the past decade. Food desert literature brings to light the definition and understanding of areas of people who are food insecure and do not have adequate access to healthy food (Rigby et al. 2012; Pine and Bennett 2014; Wight and Killham 2014; SmoyerTomic et al. 2006). Alternative food networks address food insecurity and food desert areas. They are networks that can help people have better access to healthy food, who did not have that access before. They use outlets that are alternative from corporate food markets. Literature on alternative food explores the alternative food options that communities are experimenting with in order to increase their access to and/or control over food (Goodman and Goodman 2009; Watts et al. 2005; McCarthy 2006; Sonnino and Marsden 2006; Blay-Palmer and Donald 2006; Murtagh 2010).

Recently, reflecting a broader discursive change in global food movements, geographic literature has turned its attention from identifying the problem of inequalities in the food system to questions of how people are seeking greater food sovereignty in urban and rural contexts (Kurtz 2015; Cid Aguayo and Latta et al. 2015; Jarosz 2014; Hopma et al. 2014; Bini 2016; Louis 2015; Burnett 2014; Rudolph et al. 2013; Larder et al. 2014). According to the transnational organization La Via Campesina, "Food sovereignty is the right of peoples to healthy and culturally appropriate food produced through sustainable methods and their right to 
define their own food and agriculture systems. It develops a model of small scale sustainable production benefiting communities and their environment" (La Via Campesina 2016). Spearheaded by La Via Campesina, food sovereignty was a reaction to the 1980's and early 1990's neoliberal international policies on food (Windfuhr and Jonsen 2005). La Via Campesina is an international organization that was formed by peasants, small-scale farmers, and indigenous communities that came together in order to say that the economic and environmental food crisis is due to the globalization of neoliberal, industrial, and capitalist agricultural knowledge and techniques. They are made up of 148 organizations from 69 countries (Windfuhr and Jonsen 2005). La Via Campesina launched the idea of food sovereignty at the World Food Summit in 1996 (La Via Campesina) and the grass-roots movement now has over 300 million members (Crossfield 2011).

The U.S. based food sovereignty alliance focuses on localizing the food system, making control over food local, building knowledge and skills on local sustainable food production, and working with nature by avoiding toxic inputs (US Food Sovereignty Alliance 2016). Although texts give different definitions of "food sovereignty", the majority of definitions include the right for people to produce their own food, decide what they wish to consume, and how and by whom it is produced (Windfuhr and Jonsen 2005). The definition also includes feeding people locally with local agricultural production, and having the right to access land, water, seeds, and livestock for smallholder farmers, pastoralists, fisherfolk, and people who do not have access to their own land. Food sovereignty promotes the right of countries to protect themselves from underpriced agriculture and food imports, the right to participate in agricultural policymaking, women's rights within agricultural production, and the use of community-based agroecology (Windfuhr and Jonsen 2005). Agroecology is a development concept and practice that is centered on small- 
scale farming, local production, and traditional agricultural knowledge, as a way to produce sustainable food (Windfuhr and Jonsen 2005). The food sovereignty concept is the basis of an alternative food system that is growing in popularity in international communities. Food sovereignty, as an alternative to the corporate food regime, has inspired global social movements (Alkon and Mares 2012).

In 2008, when food prices rocketed and caused a global concern for food security, the U.S. neoliberal government believed the crisis was caused by market failures and shortages (Wittman 2010). Raising food production is one strategy used by the state and international development organizations to address food insecurity. In 2009 the United Nations' Food and Agriculture Organization (FAO) Rome Summit created two pillars of how to reach global food security. The first was that food production needed to increase by $50 \%$ by 2030 in order to meet demand. The second was that food production had to double by 2050 in order to feed a world population of 9 billion people. These estimations justified the increase of biotechnological and privatized agriculture (Hopma et al. 2014). On the other hand, food sovereignty's goal to reach food security is to create radical political change that opposes the negative effects of the privatization, commercialization, and marketization of food.

The corporate food regime's concept of how to have global food security is very different from the concept of global food sovereignty. In 1974 the United Nations defined food security as "the availability, at all times, of adequate global food supplies of basic food stuffs to sustain a steady expansion of food consumption and to offset fluctuations in production and prices" (Ariza 2013, 363). According to this definition the place of production, who is producing the food, and how it is being produced is not an issue, but these are major issues for food sovereignty. After indigenous and peasant movements spoke up for food sovereignty the definition of food security 
changed, and the FAO defined food security as " ... at the individual, household, national, regional, and global levels, when all people, at all times, have physical and economic access to sufficient, safe and nutritious food to meet their dietary needs and food preferences for an active and healthy life" (Ariza 2013, 363). The UN's definition of food security still shows how they are not as concerned with the processes by which the food is produced. The definition also does not address the impact on environmental conditions. The corporate food regime works with free markets, markets assigning prices of crops, subsidies as a part of a World Trade Organization (WTO) agreement, Genetically Modified Organisms (GMOs), and land and seed privatization. Climate change is seen as an issue but industrial agriculture is seen as the only way to feed the world's population. Food sovereignty objects to every one of these elements. The neoliberal corporate food regime's goal to reach food security is to raise food production, but food sovereignty's goal for food security is to put the power over land, seeds, and prices into the hands of the local farmer (Ariza 2013).

People around the world use the concept of food sovereignty in different contexts and scales. Together Bolivia, Nicaragua, Venezuela, and Cuba have spent 100 million dollars on cooperation for food sovereignty (Leitgeb 2016). In Venezuela the government program Mission Agro Venezuela gave a billion dollars to small and medium sized grain producers and three billion to fruit and vegetables operations. Venezuela is using food sovereignty to fight for land access and to promote agroecology by producing non-GMO seeds with traditional techniques (Crossfield 2011).

Ecuador, Bolivia, Nepal, and Mali all have legal frameworks for food sovereignty ("Rice Land Grabs" 2011). In Cinco de Junio, Ecuador farmers have unequal access to land and water for their crops. In response food sovereignty was used to promote access to soil, water, and other 
resources through Article 281 of their 2008 Constitution (Partridge 2016). In Bolivia and Nepal, food sovereignty is used to work against the agro-chemicals and mono-cropping practices that threatens the countries' agrobiodiversity and crop genetic diversity (Cockburn 2014; Shrestha et al. 2012). Also, in Mali in 2007, 500 farmers, fisher folk, and indigenous people gathered to join the food sovereignty movement ("Rice Land Grads" 2011). They were fighting to stop the Mali government from industrializing and privatizing their lands. The Mali people wanted access and control over their own seeds and land. Their government was signing over land to foreign investors and letting these investors have control over the country's most useful agricultural rice lands, and this is just one example of a world-wide occurrence of "land grabs" ("Rice Land Grabs” 2011).

The global north also uses the themes and values of food sovereignty. While La Via Campesina's ideas are radical and call for political change, food sovereignty in North America has a tendency to be depoliticized and attacked by neoliberal barriers (Fairbairn 2012). Alternative food movements can have anti-hegemonic potential but often work within hegemonic market systems instead of creating alternative change (Fairbairn 2012). On the other hand, food sovereignty has the ability to point out injustices within the food system by revealing gender, race, and economic inequalities in relation to food access and distribution (Fairbairn 2012).

The food sovereignty movement in the U.S. is based on the "empowerment of communities of color, the poor, and other communities that are most impacted by the inequalities that manifest themselves in the food system" (Shawki 2012). In Chicago, the organization Growing Power runs five urban farms and uses food sovereignty values to empower low-income communities and communities of color through sustainable local agriculture (Block et al. 2012). 
Food access inequality and food deserts are major problems in the U.S. and community food security projects such as community gardening, urban agriculture, and farmer's markets are trying to address these issues. These alternative food systems can also include green grocers, local farms, community building, and youth programs. Food sovereignty's global goals are used at a community level to address individuals and communities' food systems in order to give them the right to "define their own food system, to produce food in a safe manner, to regulate production, and to choose their own level of self-reliance, rather than these being set by larger national and international organizations" (Ramirez et al., 205).

Community gardening lies within the realm of alternative food movements. Community gardens are "plots of land used for growing food by people from different families, typically urban-dwellers with limited access to their own land" (Okvat and Zautra 2011, 374). They involve multiple people working together or individually at a communal area, in order to grow food, among other things. Community gardens are shaped by the needs of the community, and they rely on the labor and aid of the community. They can be created in urban or rural areas that are in want of health and food aid or community development. Churches, individuals, community centers, city councils, extension offices, or groups of people can create community gardens.

Community gardening first emerged in the US in the 1890's (Draper and Freedman 2010, 459) as a means of combating poverty and hunger (Ghose and Pettygrove 2014a). Historically community gardens have worked to bring about better access to food in times of economic hardship. Today community gardens provide access and control over food for the food desert communities and communities with low-income families and individuals. Gardeners seem to want to support local food for local people, and have more control over the production of their 
food. Local community food systems are an element of the food sovereignty movement.

Although there is very little literature comparing community gardening to the food sovereignty movement, gardening can be examined in its relationship to the concept of food sovereignty. In Brisbane, Australia backyard gardening showed a relationship with food sovereignty (Larder et al. 2014). Gardeners' comments showed that they connect their gardening to promoting a "food-based community" and "building community". Their gardening went beyond growing food for themselves, to sharing food as a community, while sharing local gardening knowledge. They also connected their gardening to family tradition and culture. The city's emphasis on community based agriculture, using local knowledge, and connecting it all to their cultural background, are all values that are a part of the food sovereignty concept (Larder et al. 2014).

Community development can be a major benefit of community gardening. It can empower community members to be active in the community, and volunteering has positive mental and social effects for the members (Ohmer 2009). Interviews with garden members from the Community Conservation Program in Western Pennsylvania, revealed that their motivations for gardening was to beautify the community, give back to the community, and support conservation of green spaces. The members believed the gardens positively impacted their community. The volunteers were able to socialize with other members and have a connection to their neighborhood (Ohmer 2009).

In accordance with food sovereignty, youth gardening programs can help the next generation be more aware of their environment and the production of their food (Ghose and Pettygrove 2014b). Teaching children about gardening helps them learn about ecology, the environment, nutrition, where food comes from, and it can lead them to live a healthier and more 
environmentally conscious life (Ghose and Pettygrove 2014b). A study of youth in Minneapolis showed that young community gardeners have a better understanding of the food system and which foods are healthier, as compared to non-gardening youth (Corrigan 2011). Youth gardening programs and projects can improve children's diets, academics, and social development (Draper and Freedman 2010).

While U.S. social movements may not use the same language that La Via Campesina does, the motives behind both scales of activism share similar goals and elements of their practice. However, U.S. food sovereignty movements can be very limited by neoliberal barriers (Clendenning 2016). The community garden movement in some ways challenges the neoliberal capitalist system. Neoliberalization entails privatization, and this creates challenges to the access of green space for gardeners. It causes cities to adopt policies that promote development and reduce spending on social services. The neoliberal government will let community gardeners use vacant land to garden, but it puts higher interests on market led and tax-revenue potentials of the land (Ghose and Pettygrove 2014a). Gardeners have to work with, against, or around neoliberal policies. Gardens can still enforce neoliberal capitalism by the selling of produce to farmer's markets and restaurants. Selling produce is seen as an economic development benefit of growing gardens (Draper et al 2010).

Neoliberal policies make it difficult for community gardens to have access to secure land. Like countries in the global south, community gardeners have to fight for their right to access land and resources they need to grow local food. Urban community gardens often use vacant lots for their plants. In Milwaukee, Wisconsin gardeners have to get permission to use the land by the city planning department. The department gives gardeners permits for six month or three year periods that must be renewed annually and can be revoked at any time. They must apply, provide 
a site plan, have support from sponsors, and pay their fees. Any real estate development potential a land might have is a threat to the future of the garden (Ghose and Pettygrove 2014b). In a study of eight gardens in Winnipeg, Canada the gardens were governed by land use legislation, the City of Winnipeg Charter Act, zoning by-laws, development plans, and city policies. The community garden policy statements the city had were vague and had no concrete goals. Gardens get stuck in the middle of this struggle with polities and city planning, but there is hope that city officials in Winnipeg will see the importance of the gardens and buy land in order to use it for a multi-use park and community garden center, or put gardens on community center property (Mikulec et al. 2013). When gardeners are challenged there have been cases where they fight back with resistance. The South Los Angeles Community Garden and Urban Community Garden Programs were shut down after private ownership took over, but gardeners campaigned, marched, protested, and talked to city council members to restore the garden. In New York as well, a similar situation occurred and celebrities joined in on the protest (Draper and Freeman 2010).

Community gardens have a way of resisting hegemonic forces while also recreating them. According to Rina Ghose's studies of Milwaukee community gardens, these gardens have a hegemonic system, because the volunteers with the physical ability, knowledge, and time to work with the gardens are the ones able to benefit from the garden. Gardens also interact with the community and bypass the state, and this is what the dominant neoliberal government advertises. The garden tries to resist the hegemonic marginalization of the minority populations in the city by giving them access and control over their food. On the other hand, the garden reinforces the neoliberal government by leaving out the state's responsibility for providing social services (Ghose and Pettygrove 2014b). 
Another challenge to gardeners is the need for skilled and dedicated volunteers. Food sovereignty could be used to inspire gardeners to fight for their right to access the resources they need to have a sustainable garden. Gardens require energy and resources, such as tools, volunteers, and seeds (Mikulec et al. 2013). A study of community gardens in Milwaukee neighborhoods showed that networks with organizations helps gardens find the necessary support and volunteers they need. These networks can be with the government of the city, nonprofits, churches, or schools. These social networks were important to overcoming barriers to their gardening (Ghose and Pettygrove 2014a).

Donna Armstrong studied twenty community gardens in upstate New York, five of which were being run by extension agents and the rest by private organizations. Of the 20 gardens $90 \%$ provided technical support to the individual gardeners, $30 \%$ had education classes, $55 \%$ provided seeds and seedlings, $40 \%$ tested their soil, and $60 \%$ of the programs prohibited chemicals or chemical fertilizers (Armstrong 2000). These statistics show how organizations, whether state funded or private, are able to support a garden's needs. Fewer are able to test their soil, but more than half are prohibiting chemicals, which means they are environmentally conscious about their gardening practices, as food sovereignty would approve of. Also, $28 \%$ of the gardens had a local school or church maintaining a plot in the community garden. Organizations like Hunger Action Network and AmeriCorps are also able to help supply the gardens with workers (Armstrong 2000). These institutions and organizations are examples of networks that play a major role in supplying gardens with the needed volunteers.

\section{History of Gardening in the U.S.}

The early settlements of the United States survived off gardens, by gardening the same plants that the Native American's ate, corn, beans, and squash. In the $18^{\text {th }}$ century class status 
separated the function of the gardens. The lower class citizens had gardens for sustenance and the higher class used elaborate gardens as a socioeconomic status. In the $19^{\text {th }}$ century gardening became less popular and more of a recreational activity. High levels of urbanization and technology caused the creation of markets and grocery stores, and the lowering of gardening activity. Urban people had less "time, space, and desire" for gardening (Schupp and Sharp 2012, 94).

Household and community "War Gardens" during WWI and "Victory Gardens" during WWII were used 54\% of the time for economic reasons, and showed an increase in gardening activity when a crisis arose (Schupp and Sharp 2012, 95). The U.S. Department of Agriculture during WWII produced around 40\% of the country's fresh vegetables from 20 million gardens across the country. In America and Britain, War and Victory Gardens during WWI and WWII were able to sustain the masses by the state telling citizens that "food will win the war", and to “dig for victory" (Hayden-Smith 2014; Way 2015). Posters, print media, articles, speeches, and magazines spread the message of how important gardening would be as a part of the war effort. Through themes of patriotism and nationalism the federal government was able to motivate citizens to garden, most of those citizens being women and children. Gardening at the home front could release pressure on the food supply so that more food could be sent to the European allies and more room would be left in the cargo spaces of ships (Hayden-Smith 2014). When food imports to the UK were slowed down, gardening was promoted in the US as a way to personally contribute to the war by sustaining yourself and sending food to the soldiers and allies at war (Hayden-Smith 2014; Way 2015; Gowdy-Wygant 2013). During the World Wars gardening was seen as important to national security (Hayden-Smith 2014).

After WWII community gardening died off and then gained popularity again in the 
1970's (Lawson 2005 cited in Draper and Freedom 2010) and by the mid-1990's over one million people were participating in over 15,000 community gardens throughout the United States (Malakoff 1995 cited in Okvat and Zautra 2011). Then gardening increased even more in 2009 with the growing of "recession gardens" (Sutter 2009 cited in Draper and Freedman 2010). With fears of the biotechnology and pesticide usage in our food system, and the ever increasing distance between the average consumer and the workings of the food system, today's community gardening has been a way to reconnect people with their own food (Turner et al. 2011). Today gardening is still being used in times of economic hardship. A study of data from the 2008 Ohio Survey of Food, Agriculture, and Environmental Issues showed a positive relationship between gardening and economic hardship in Ohio (Ohmer 2009).

\section{History of Gardening in WV}

After the Civil War subsistence farming decreased. In Appalachia people were abandoning their hillsides for coal company towns. From the 1880's to the 1930's West Virginia saw the new capitalist system take over subsistence gardening (Stoll 2014). Capitalists had to "capture the garden" by changing the self-provisioning mountain culture (Stoll 2014). They would have gardens of beans and squash, and what was growing in the garden showed the identity and culture of the family (Stoll 2014). They were self-provisioning by having cattle and pigs, forests that could be foraged, and fields of corn for whiskey, starch, and animal feed. Logging and the creation of the mines changed this sustaining culture (Stoll 2014). The coal camps let the miners have gardens, but the miners were dependent upon them, because they were not able to survive on the small amount of wages they were given for the company store. If a person left the mine, they were separated from the garden and starvation could set in. The company's control over the gardens kept them working without the ability to be self-sustaining 
anymore. Gardening was beginning to be called "primitive" and "outside of modern society" (Stoll 2014, 89-90). Gardens challenged the progress of capitalism and the industrialized system (Stoll 2014).

In Arthurdale, WV the history of coal mining, the Great Depression, and gardening can still be seen today. Arthurdale was a homestead subsistence farming community supported

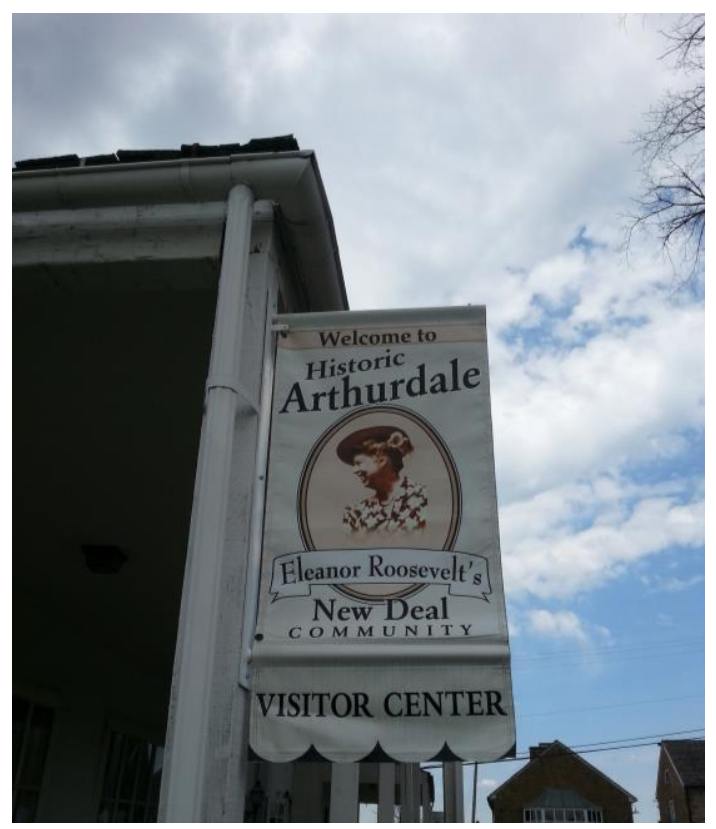
by Eleanor Roosevelt during the Great Depression. In the early 1930's many West Virginians were unemployed and hungry. The Roosevelt Administration established the Federal Subsistence Homestead Division in order to create communities that were self-sustaining and could aid the unemployed coal miners and their families. West Virginia had three homestead communities, Arthurdale in Preston County, Eleanor in Putnam County, and Tygart Valley Homestead in Randolph County (Arthurdale Heritage). The program was a federally funded project that tried to help the coal mining community of Scotts Run after the massive job losses. Several members of the new Arthurdale homestead would come from Scotts Run. The homestead included farm plots and three different types of housing that members were qualified for based on their income.

Members of the community were chosen to participate if they passed an exam that tested their knowledge on farming and gardening. The exam had questions pertaining to seed identification, planting techniques, and if they knew garden techniques based on the phases of the moon. Since the community was meant to be self-sustaining, the government needed people 
who would have the knowledge to survive. Bedsides farming and gardening, the homestead taught themselves and sustained themselves through jobs such as sewing, metal work, and woodworking.

In 1947 the federal government liquidated its holdings in Arthurdale and the homes were sold to private ownership (Arthurdale Heritage). When the program ended the citizens of

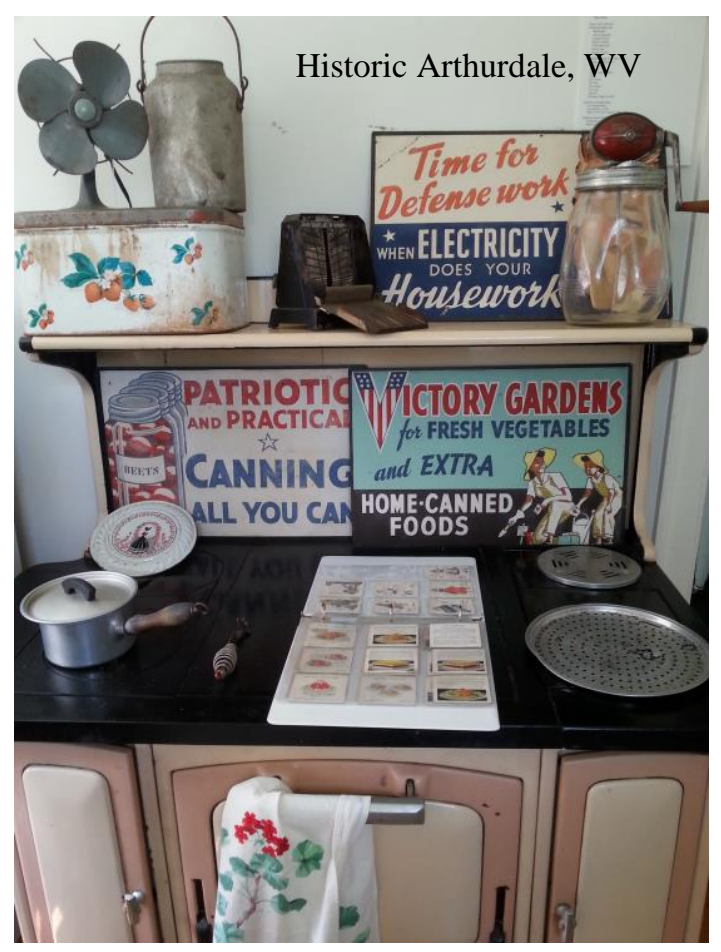
Arthurdale could buy their homes for the price of what they were paying for a year's rent. If the people could not afford to buy their house they had to leave. Arthurdale today still has some surviving buildings from the original community. Today a food co-op has taken the place of the old Esso gas station and a new Victory Garden has been rebuilt with the help of the Preston County Master Gardeners. The site still stands as an example of when subsistence gardening was used as a way to combat a time of economic crisis.

\section{Chapter 3: Research Questions}

West Virginia has come a long way from the history of gardening in the 1880's to 1940's. What was once done as a necessity is now done for pleasure, and instead of the government enforcing the use of self-provisioning gardening, it is seen as no longer necessary. In order to understand how food sovereignty is still being used today and how it relates to the global food sovereignty movement, I used these questions to help guide me through my research. 
1. How does community gardening contribute to food sovereignty in WV?

2. To what extent are garden leaders trying to promote food sovereignty in WV?

\section{Chapter 4: Research Design}

In order to understand how community gardening is contributing to food sovereignty in West Virginia I used qualitative methods. Qualitative methods help show the motivations, thoughts, and feelings behind the action of community gardening. I used surveying, interviewing, and participant observation, in order to look at community gardening and the garden leaders from different angles that could then be compared and used together. From February to October 2016 I conducted participant observations at the Conscious Harvest Cooperative Garden in Morgantown, WV. June to July of 2016 my survey was conducted, and from December to January of 2016 my interviewing was completed. In addition, I started my analysis and writing my thesis January to March 2017.

First, I conducted preliminary interviews and surveys in order to understand how community gardening in WV functions. While doing preliminary research throughout the Spring of 2016 I mapped some of the community gardens in West Virginia and learned that most of the gardens that can be found online are located in the most urban areas of West Virginia. I also collected basic information on four WV community gardens through interviews, in order to test out what my survey questions could be. I interviewed garden leaders as key informants at the Conscious Harvest Garden, Alderson Garden, Fairmont Community Garden, and the East End Community Garden in Charleston. This information included details about the history and use of the garden. Through these preliminary interviews, I learned some of the differences and similarities between the gardens. These were all gardens that rented plots to community members annually, and two of the four gardens had communal plots where the food was being grown for 
food pantries. Fairmont and Charleston had communal plots specifically for children. The Charleston garden had a communal plot for veterans and the Fairmont garden had plots for people with disabilities. The Alderson garden did not have a communal plot, instead organizations had their own plot and the elementary school sometimes donated to the town's food pantry from their plot. The individual gardeners also had the option to sell their produce to the Green Grocer Co-op in town or to the farmer's market. These details helped me shape the questions I would form into my survey and interview guide.

Next I worked on surveying community gardens across the state as a way to understand the organization and function of the gardens. Surveying gave me the ability to compare and contrast the different gardens in West Virginia. By surveying I can now understand the differences and similarities in the gardens' organization, creation, and goals. The survey I created was sent through email or conducted over the phone with community garden leaders across the state (Appendix A). I only spoke with garden leaders, as key informants of the gardens. School gardens were not included because of the vast differences in objectives between a school garden and a more general community or neighborhood garden. The contact list I started with had around 30 gardens listed, some being gardens that did not actually exist or were no longer running. The list narrowed down to 24 community gardens in WV. I was able to contact and confirm the existence of 19 community gardens across the state (Map A and B). I surveyed the 19 gardens and asked questions about their consent to share the garden's location and contact information with WV FOODLINK. WV FOODLINK collects data on food outlets and food security in the state, in order to display the information through their website, so that WV citizens can be better connected to the food access around them. The survey also asked about the creation of the garden, the type of garden it was and what they were growing, how they got their 
financial and labor support, and how the garden was organized through its plots or beds. A garden could be built just to give community members a place to garden for themselves, or the garden could be a communal effort to grow food for food pantries, and then there are gardens inbetween that do a bit of both. I also asked about the cost of the plots, if they have a garden contract that the gardeners must sign and abide by, and what the contacts see as the benefits and challenges to their gardens.

\section{Map A}

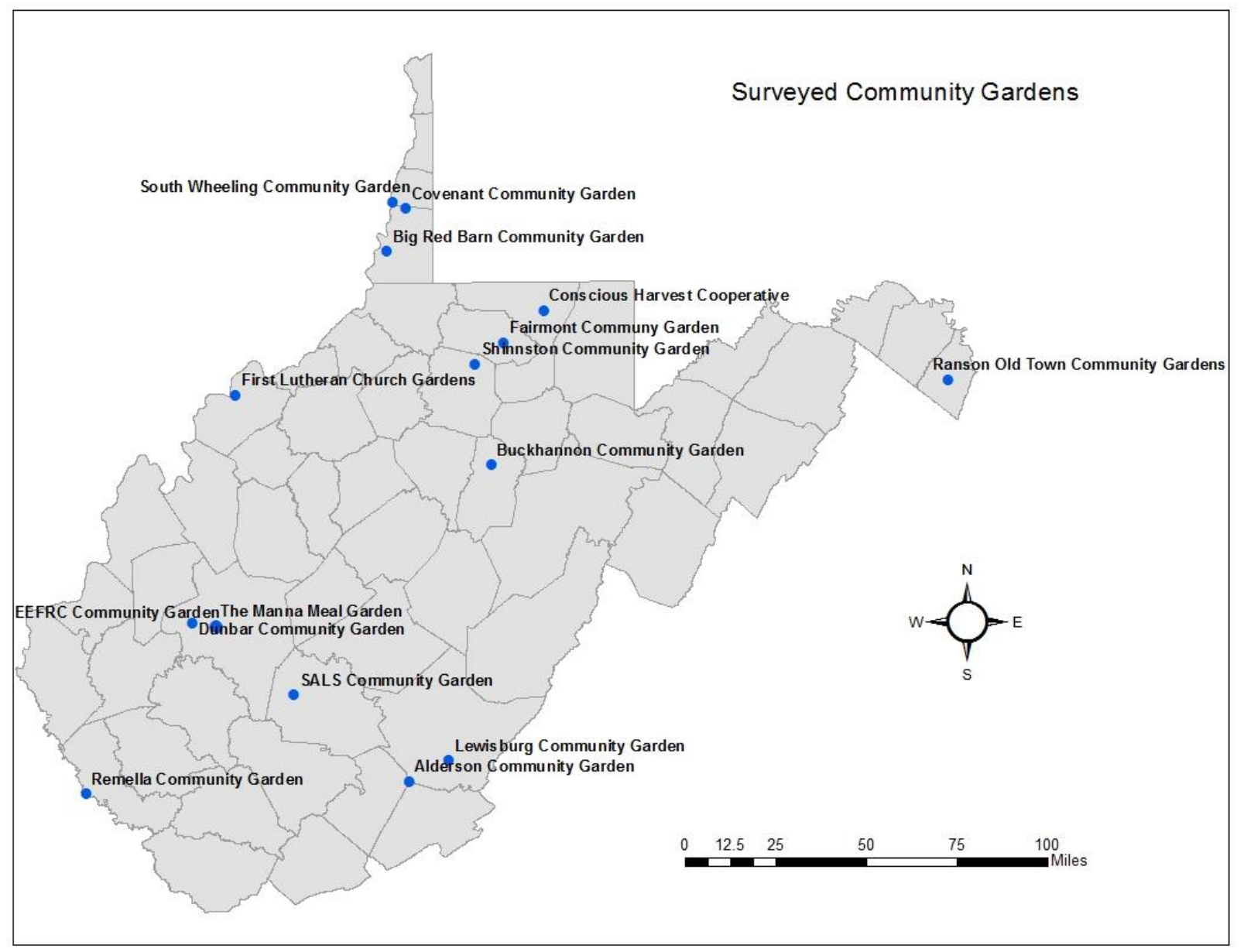




\section{Map B: Cluster of surveyed gardens in Charleston, WV.}

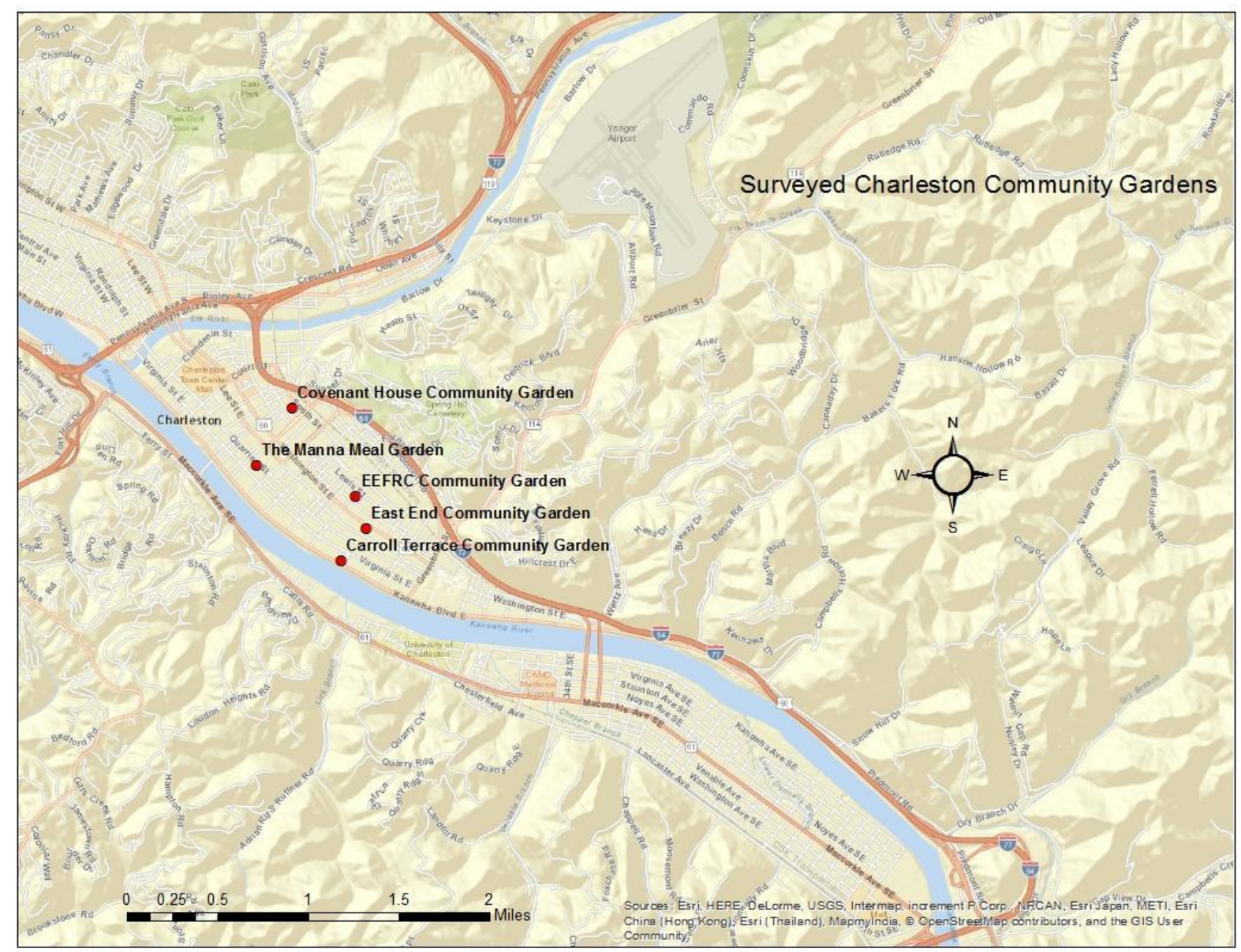

The ethnographic research for the gardens took place during the Summer of 2016 when

the gardens were active. I observed gardening at the Conscious Harvest Cooperative Garden in Morgantown, WV. I attended Conscious Harvest's work days and learned about gardening by participating alongside the other members. I was able to help plant seeds, pull weeds, and harvest. By participating with the garden I was able to better understand how to be a community gardener and the work it takes to garden. I was also able to take pictures of the garden, and I visited and took pictures of the Buckhannon, Alderson, East End, and Big Red Barn Community Gardens in Buckhannon, Alderson, Charleston, and Moundsville, WV. The locations of the gardens and contact information for the leaders of the gardens were shared with WV 
FOODLINK, so that they can share the information on their website. I also attended the 2016 TryThisWV Conference in Buckhannon, WV and visited the historic town of Arthurdale, WV. Interviews develop detailed descriptions while receiving multiple perspectives. Interviews are able to show more detailed experiences, thoughts, and feelings (Weiss 1994). For

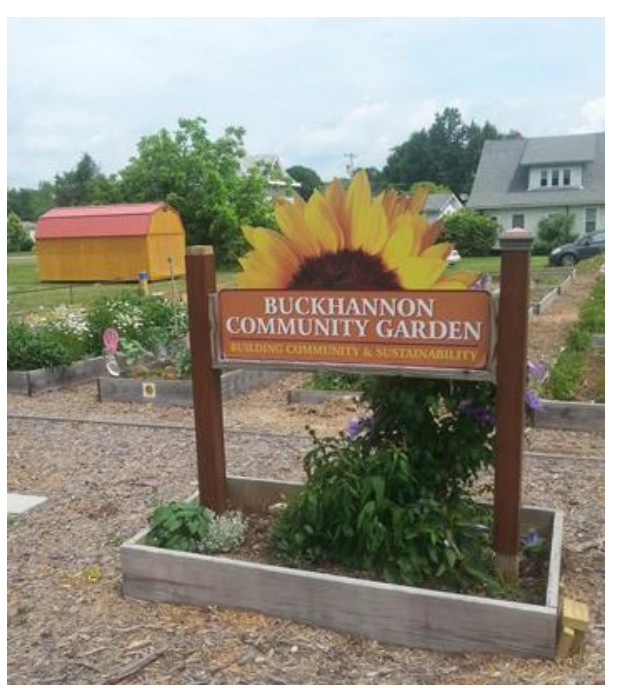
my interviews I went back to the garden leaders I surveyed and I interviewed them about what they specifically do and provide for the garden, as well as what they are trying to promote and give access to through the garden. These interviews were meant to hone in on how the garden leaders' goals for the gardens relate to food sovereignty. I interviewed the garden leaders based on the interview guide I created (Appendix B). I was able to interview 11 of the 19 garden leaders I surveyed (Map C). I hoped to understand how their vision for the garden lined up with food sovereignty goals and concepts. Garden leaders are often the force that controls the future and stability of the garden, so they are the main person to speak to when it comes to learning about the garden's goals and function. 


\section{Map C}

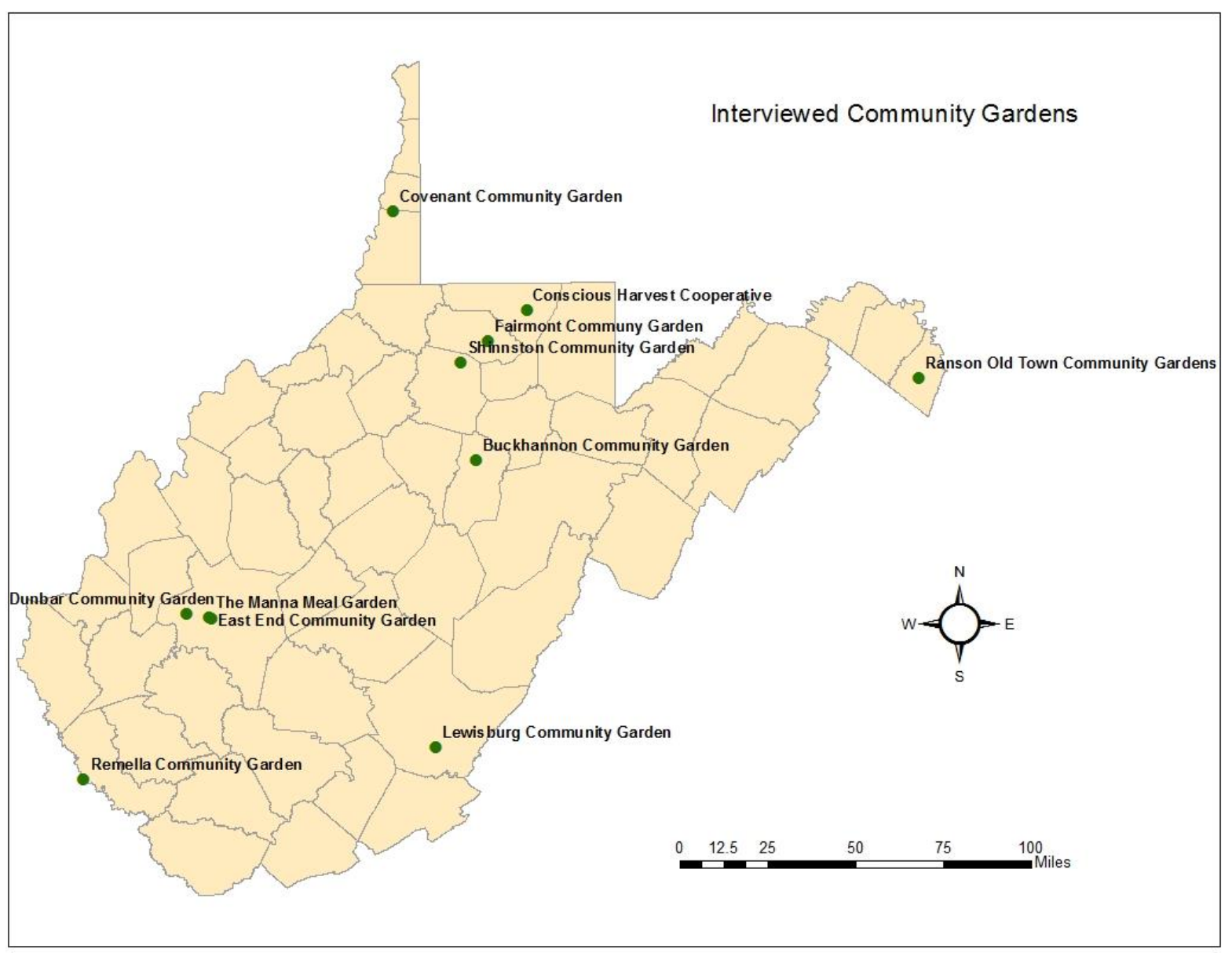

\section{Chapter 5: Coding and Analysis}

I coded my survey results based on themes that were mentioned and brought up by the garden leaders more than twice. I took the spreadsheet of results I had from the survey and colored coded recurring themes based on the questions I asked. Some survey conversations were recorded over the phone and quotes were taken from my recordings. Some of the participants took the survey through email and their own written responses were used for quotes. I used a similar methods with my interviews. Most of the interviews were recorded and I took notes on 
all of the conversations. My notes were then shortened and put into an excel spreadsheet for me to color code recurring themes. Quotes and analysis were also taken from my notes of the conversations, as well as the recordings. When visiting gardens I took pictures and sometimes took notes, while at other times I worked as a garden member would.

\section{Chapter 6: Preliminary Research Findings}

I surveyed 19 community gardens across West Virginia. The youngest garden I surveyed was founded in 2015 in Alderson, WV, while the oldest was founded in 2005 in Charleston, WV. The gardens were usually using either ground gardening, raised beds, or both, and some gardens used other additional methods such as high tunnels and hay bales (Graph A). Ground gardening is the traditional planting of seeds or seedlings in the ground; usually this form of gardening is divided up into plots for individual gardeners to use, or they could be gardening all together on divided rows. Raised beds are usually made from wood and contain soil lifted off of the ground within the wooden box. The dimensions of the beds vary, several were around 4 by 8 feet. This method is a way to assign one bed or more to an individual gardener.

\section{Graph A}

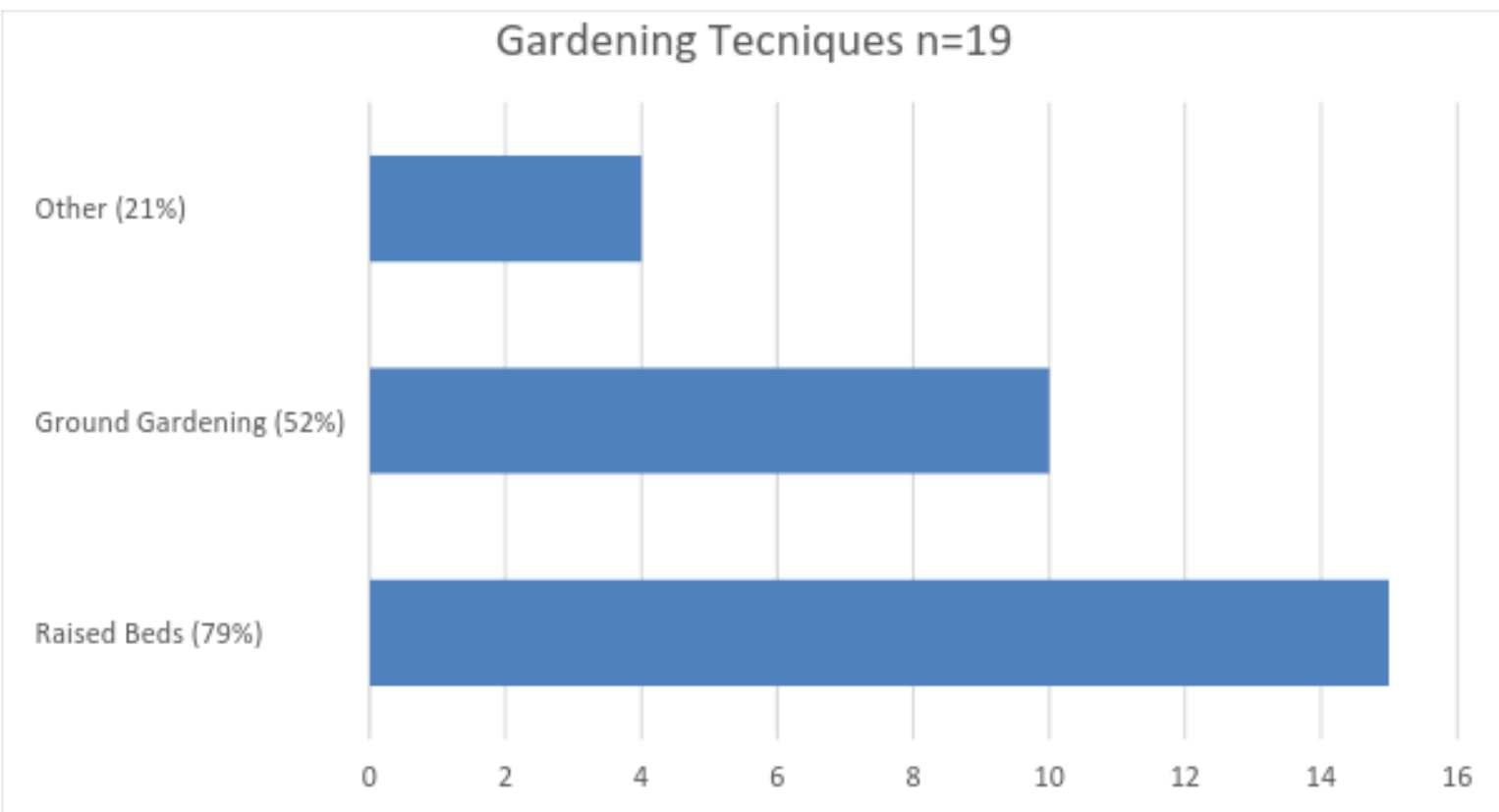


Most of the gardens have individual beds or plots for people in the community to rent out, with the exception of 5 gardens that had no individual beds or plots because they were communally gardening in order to donate all of the food. Of the gardens that had individual beds/plots, the Carroll Terrance Apartment

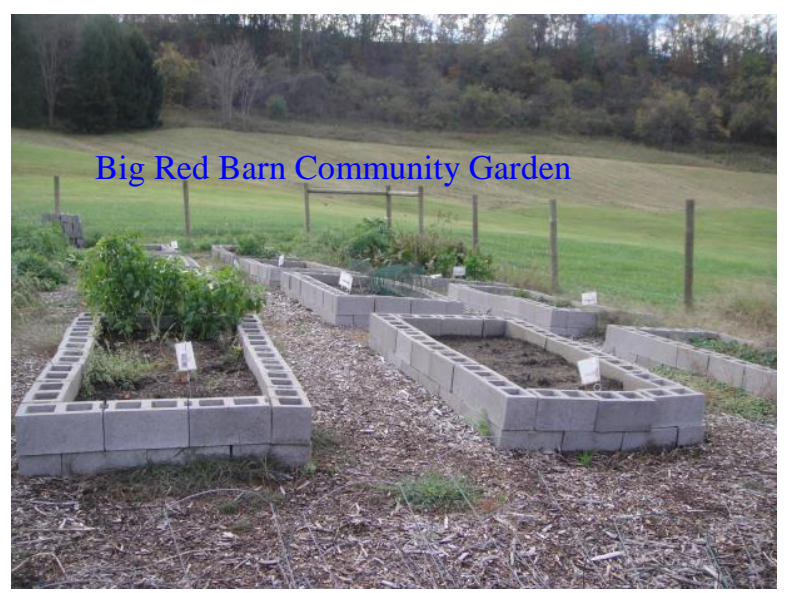
Complex in Charleston, WV had the highest number of beds/plots and the highest number of participants that were using them. The Big Red Barn garden in Wheeling, WV had the smallest number of beds/plots, while the Fairmont garden in Fairmont, WV had the lowest amount of participants (Graph B). Several gardens rely on volunteers for their gardening, especially gardens that have no individual beds/plots and are gardening communally. Manna Meal in Charleston, WV had the largest number of volunteers, with an estimated 500 people helping with the garden in 2016. In second place, was the Ranson Old Town garden in Ranson, WV with 134 volunteers in 2015. 


\section{Graph B}

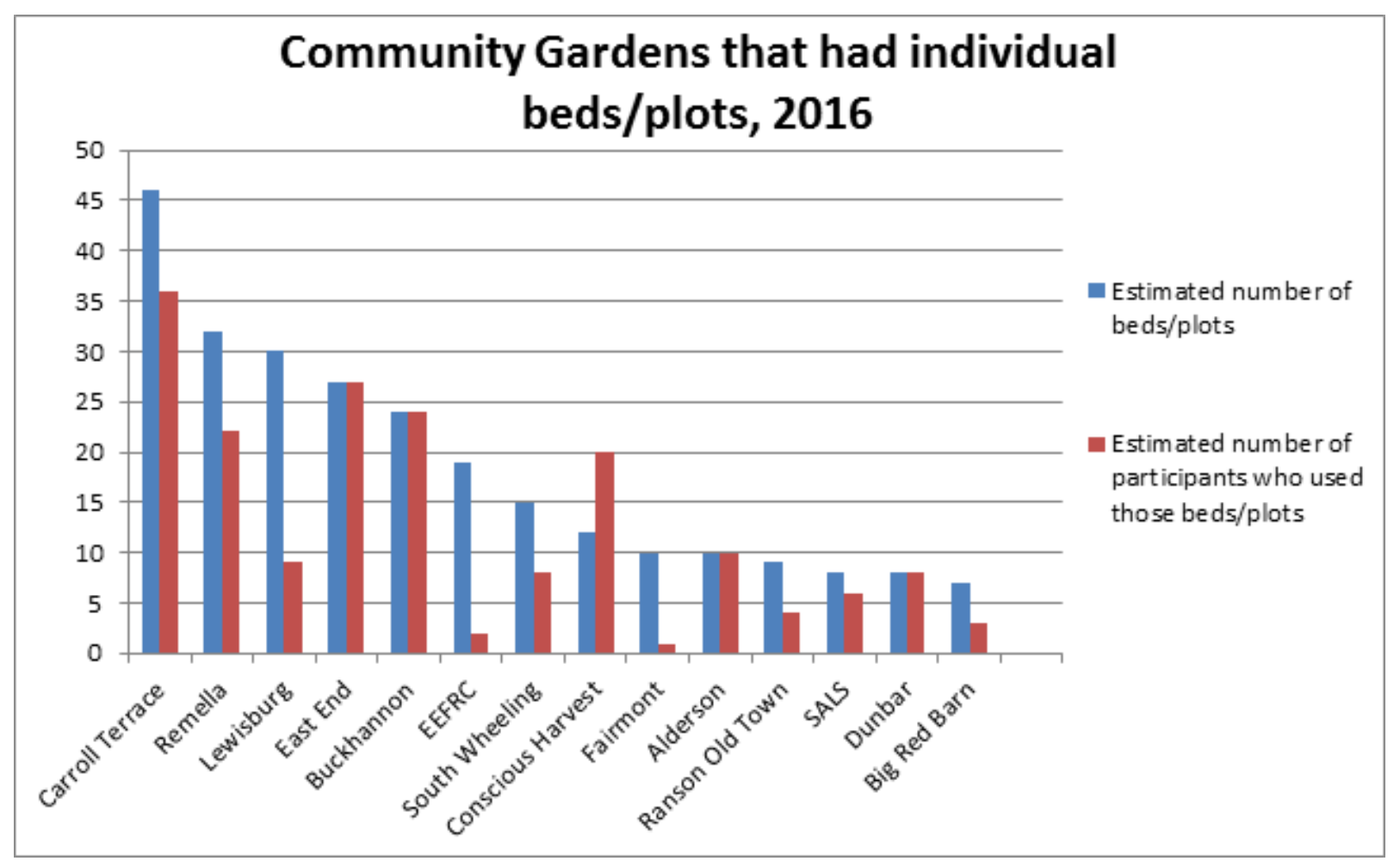

The gardens were growing mostly vegetables. Some gardens were also growing fruit,

flowers, and/or herbs (Graph C). Most of the gardens were fenced or gated, had their soil tested, did not allow chemical pesticides to be used in the garden, and had liability insurance, that is sometimes taken care of by the city if the garden is on city owned land (Table A). 


\section{Graph C}

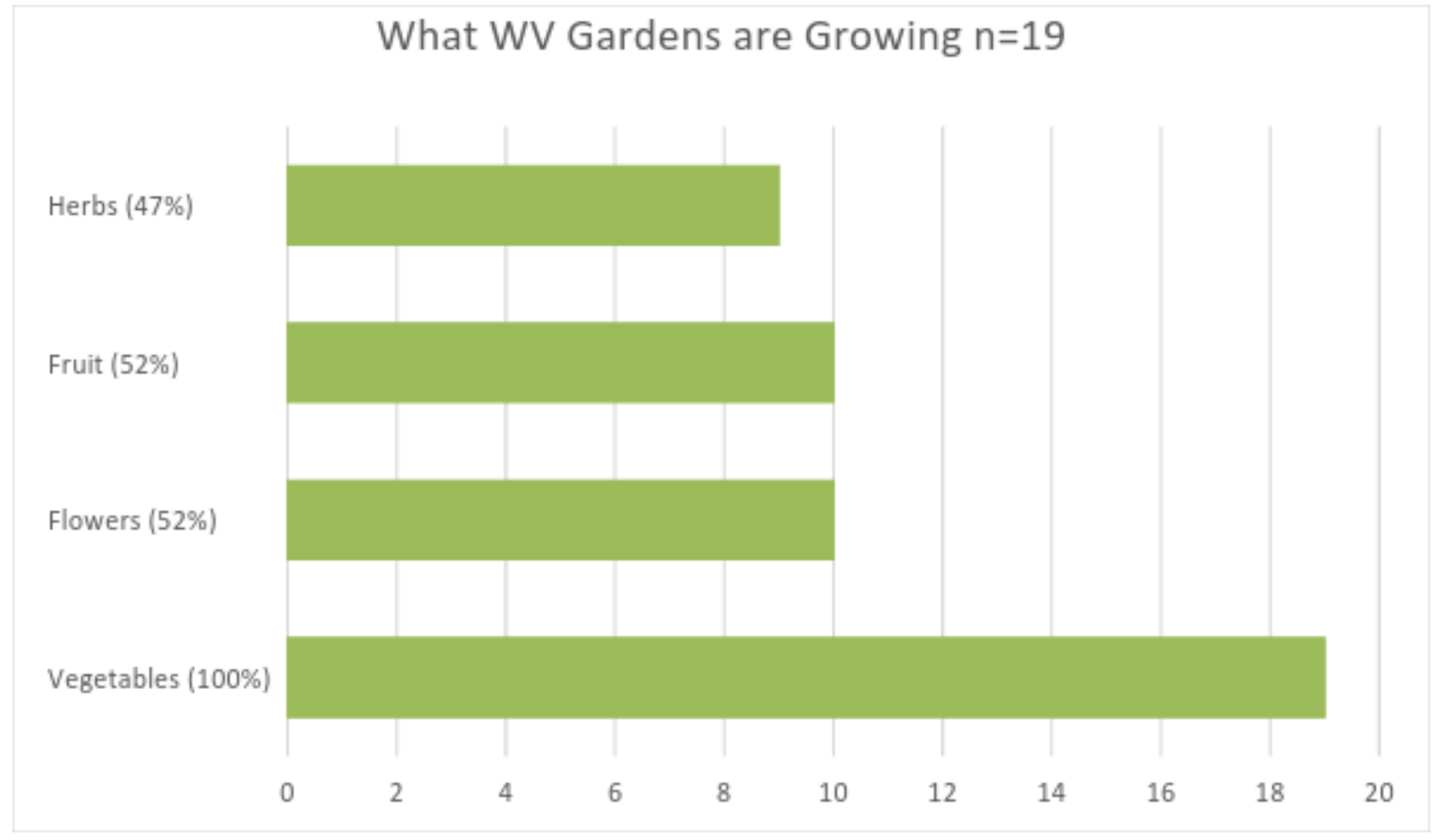

Table A

\begin{tabular}{|l|l|}
\hline Question & Response $\mathrm{n}=19$ \\
\hline $\begin{array}{l}\text { Is the garden } \\
\text { fenced or gated? }\end{array}$ & $\begin{array}{l}14 \text { yes } \\
5\end{array}$ \\
\hline $\begin{array}{l}\text { Has your soil been } \\
\text { tested? }\end{array}$ & $\begin{array}{l}11 \text { yes } \\
8 \quad \text { no }\end{array}$ \\
\hline $\begin{array}{l}\text { Do you allow } \\
\text { chemical } \\
\text { pesticides to be } \\
\text { used in the } \\
\text { garden? }\end{array}$ & 7 yes \\
\hline $\begin{array}{l}\text { Do you have } \\
\text { liability } \\
\text { insurance? }\end{array}$ & $\begin{array}{l}13 \text { yes } \\
\text { inso }\end{array}$ \\
\hline
\end{tabular}

By studying the gardens I have surveyed, I came up with six categories of gardens (Diagram A). "Neighborhood gardens" can be "multi" or "individual", based on whether they have plots for just individual community members, or if they have community member plots and 
plots for giving away food to food pantries or other kinds of local donations. There are also pantry gardens that are created by food pantries for the distributing of food by the food pantry, apartment complex gardens that are for the people living in the residential building, community center gardens created by community aid organizations, and church gardens that are created by churches.

Gardens on publicly owned city land have a higher chance of having a contract that lays down rules they must follow to be a garden participant. Nine (47\%) of the 19 gardens had contracts that had to be signed by a member in order to have a plot or bed in the garden. These contract rules can include keeping your area clean, helping on end of the season work days, and if you leave your area unattended for over two weeks without informing the leader of the garden, your spot can be taken from you and given to someone else, while your food can be donated. Non-contract gardens give an appearance of being less organized than contract gardens. The leader of the Big Red Barn Community Garden in Moundsville, WV said that her garden contract states that the gardeners, "must use the garden in a safe manner (no recklessness), must maintain beds or inform us any lapses in gardening care (i.e. vacation), adults must accompany children, [and] they must respect any re-entry time frames after herbicide/insecticide application by Agriculture Program Assistant.”

Ten $(52 \%)$ of the gardens were on privately owned land, while the other $9(47 \%)$ gardens were on publicly owned land, this land is usually owned by the city or county. Six (31\%) of the gardens had annual fees that have to be paid in order to be a part of the garden. These fees can vary from $\$ 5$ to $\$ 75$ dollars depending on the garden.

Over half of the gardens were giving away food to either food pantries, food banks, Meals on Wheels, local donations, soup kitchens, or refugee centers. A couple of the garden 
leaders expressed how they only donate when members of the garden stop maintaining their plots, and their contract says they can harvest their food and give it away if they have not maintained their plot for an extended period of time. Also, 5 (26\%) of the gardens are giving away all the food they grow and have no individual plots. The Shinnston Community Garden donated 1,000 pounds of food to their local pantry in 2016. The First Lutheran gardens located in Parkersburg, WV were able to give away 7,000 pounds of free food to the neighborhood last year from a wooden stand they built.

\section{Diagram A}

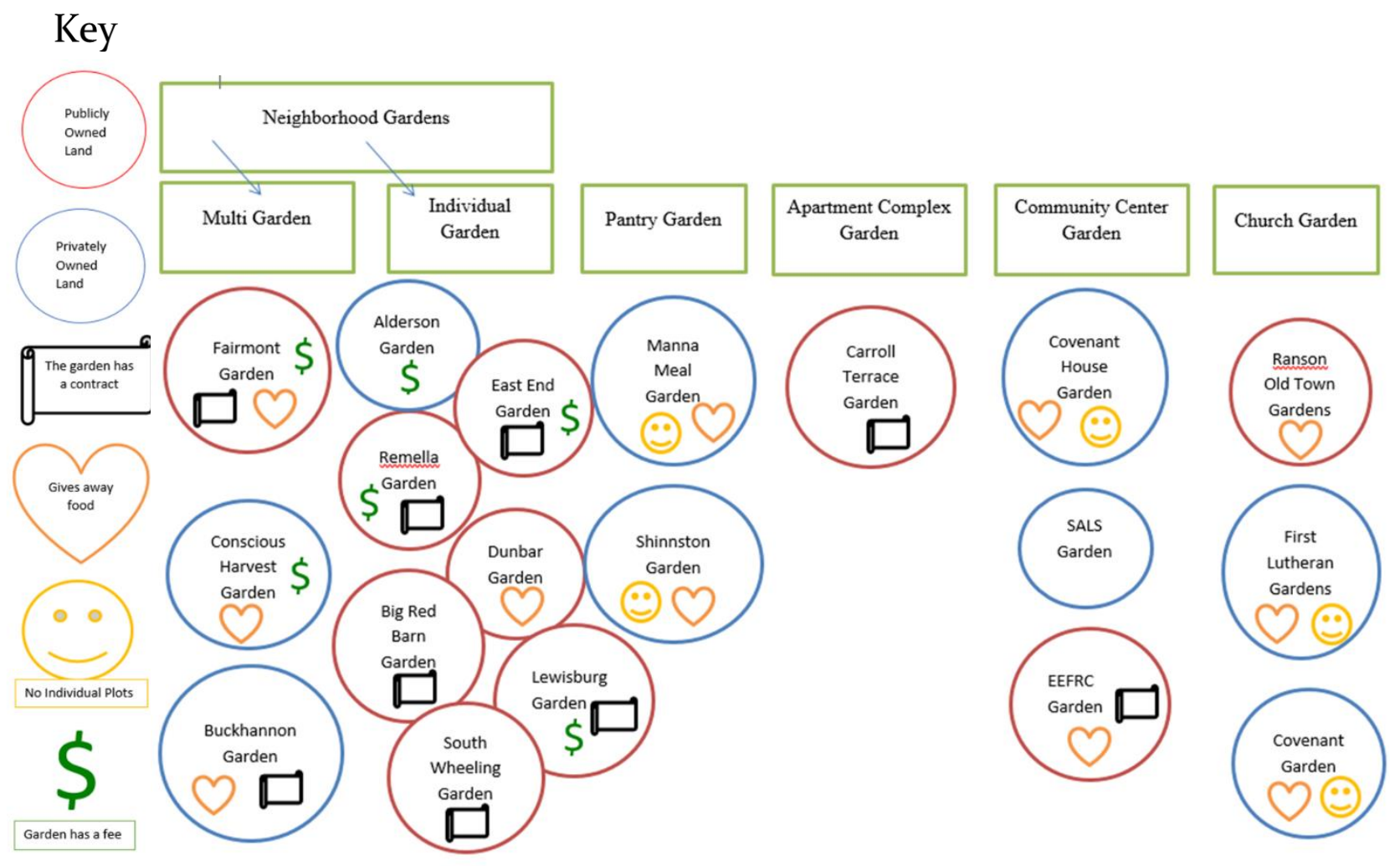

Universities and extension helped create 7 (36\%) of the gardens, churches helped create 4 (21\%) of the gardens, and city organizations such as the Wheeling Fire Department, Charleston Urban Renewal Authority, and Williamson Development Authority helped create 3 (15\%) of the 
gardens. Most of the gardens were created either for food security, or community and health aid. Of the 19 gardens surveyed $12(63 \%)$ said that the garden was created for food security reasons, in order to fill a gap in the local food system or provide fresh healthy food for people who did not have access to it before. Six (31\%) of the gardens said that the garden was created in order to aid in community development or to help the health of the community.

The gardens were financially supported by a variety of outlets. The rent for the individual plots is used to fund the garden, community grants and donations are used, and TryThisWV grants are applied for and were mentioned by 4 of the gardens. TryThisWV is a West Virginia grassroots movement that is funding projects across the state with small grants, with the goal to help the health of the state. Participating organizations range from community gardens and food pantries, to people who are using the grants to encourage kid's programs that promote bike riding for exercise. Other grants mentioned were from Grow Appalachia, Churches of America, Walmart, BB\&T, and Kitchen Gardeners International. Of the organizations that help offer aid and volunteers for the gardens, 7 (36\%) leaders said Master Gardeners help with their garden, 6 (31\%) gardens mentioned church members, 6 (31\%) mentioned a university, students, or an education board, and 4 (21\%) gardens said YouthWorks, Boys and Girls Club, and/or Boys and Girls Scouts help volunteer with their garden.

The garden leaders said the challenges the gardens are facing are the need for more participation or volunteers, weather and maintenance problems with the gardening, and community members stealing food from the garden. The highest challenge that the garden leaders spoke about was how their garden needed more participation, or faithful and dedicated volunteers, or more labor. The second highest challenge to the gardens was how they have to deal with harsh weather conditions, animals and insects, and/or weeds. Too much rain, flooding, 
pest management, keeping away animals such as groundhogs, and having to keep up with large amounts of weeds were all mentioned as challenges. The third highest challenge that the gardens mentioned, was that people from the neighborhood were taking food from the garden that was not theirs. Gardens such as the East End Community Garden in Charleston, WV have started planting vegetables that are not as common in their coloring or shape so that people walking by in the neighborhood would be less likely to steal their food. When a garden has an issue such as this one it is advised for garden leaders to have a "Vandal's Garden" outside of the perimeter of the community garden, so that neighborhood people can take from the Vandal's Garden and not take from community members' individual plots or beds. This method was mentioned at the 2016 TryThisWV conference, which was held at West Virginia Wesleyan College in Buckhannon, WV.

The garden leaders said that the main benefits of the gardens are its ability to promote health benefits, to bring the community together, to teach adults and children about gardening, to help the hungry and food insecure, and to promote a good exercise/relaxation activity. Eight gardens talked about "fresh" food and providing healthier eating options as a benefit of the garden. Four gardens specifically mentioned children as a target for their outreach for healthier eating and education. The leader of the Big Red Barn Community Garden, stated that they "try to

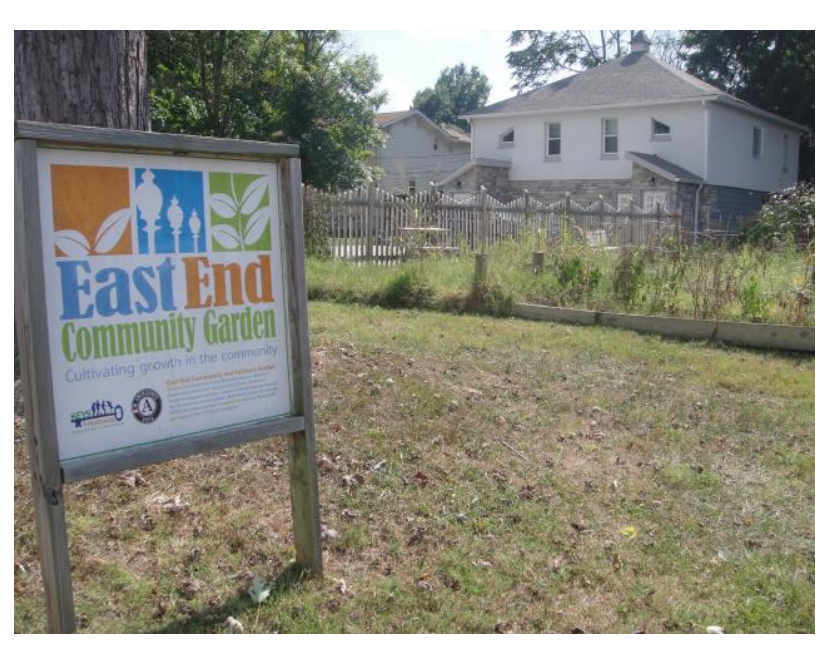
target youth and low-income families to get them involved in gardening and eating healthier." Seven of the gardens have plots/beds specifically for children. Seven gardens also mentioned a benefit of the garden being the bringing together of the community in order to 
work together and have a relationship with one another where they can share their gardening knowledge with one another. Seven gardens also said that the garden is able to help educate people about gardening and help them learn new skills. The leader of the Covenant House Community Garden in Charleston, WV, stated that they "wanted to give program participants the opportunity to volunteer in the garden to develop their own gardening skills and talents." Five garden leaders said that the main benefits of the garden were how it is able to provide food for people who need it, due to low access to healthy food or because of their financial situations. The leader of Remella Community Garden in Williamson, WV said that the garden was created because "Mingo County is a food desert, so there is very little access to fresh produce", and a benefit of the garden is that it is able to help low-income families. The leader of SALS (Southern Appalachian Labor School) Community Garden in Beard's Fork, WV stated that she is working with the garden in order to help the children that come to their after school program just to get a hot meal. After seeing the turnout of children showing up just for food, she stated, "We didn’t know people were starving", and now the garden is able to help feed the local children. Finally, 3 gardens said that exercise or relaxation were major benefits of the garden.

\section{Chapter 7: Research Findings: Participant Observations and Interviews}

I was able to interview $11(57 \%)$ of the original 19 gardens from my surveying. Three were multi gardens with individual plots and plots for giving away food, 4 were individual gardens (with one that does give food away but does not have a plot dedicated to giving), 2 were pantry gardens, and 2 were church gardens. Of the 11 gardens 7 (63\%) were giving away food as donations and $4(36 \%)$ were not. Since these gardens have different structures and goals, some of the gardens have members with individual plots (ground gardening) or beds (raised bed gardening), while the pantry gardens and one of the church gardens has only volunteers working 
for the garden in a more communal fashion (Graph D). Ranson Old Town had the largest amount of volunteers, while Fairmont had the lowest amount of gardeners.

\section{Graph D}

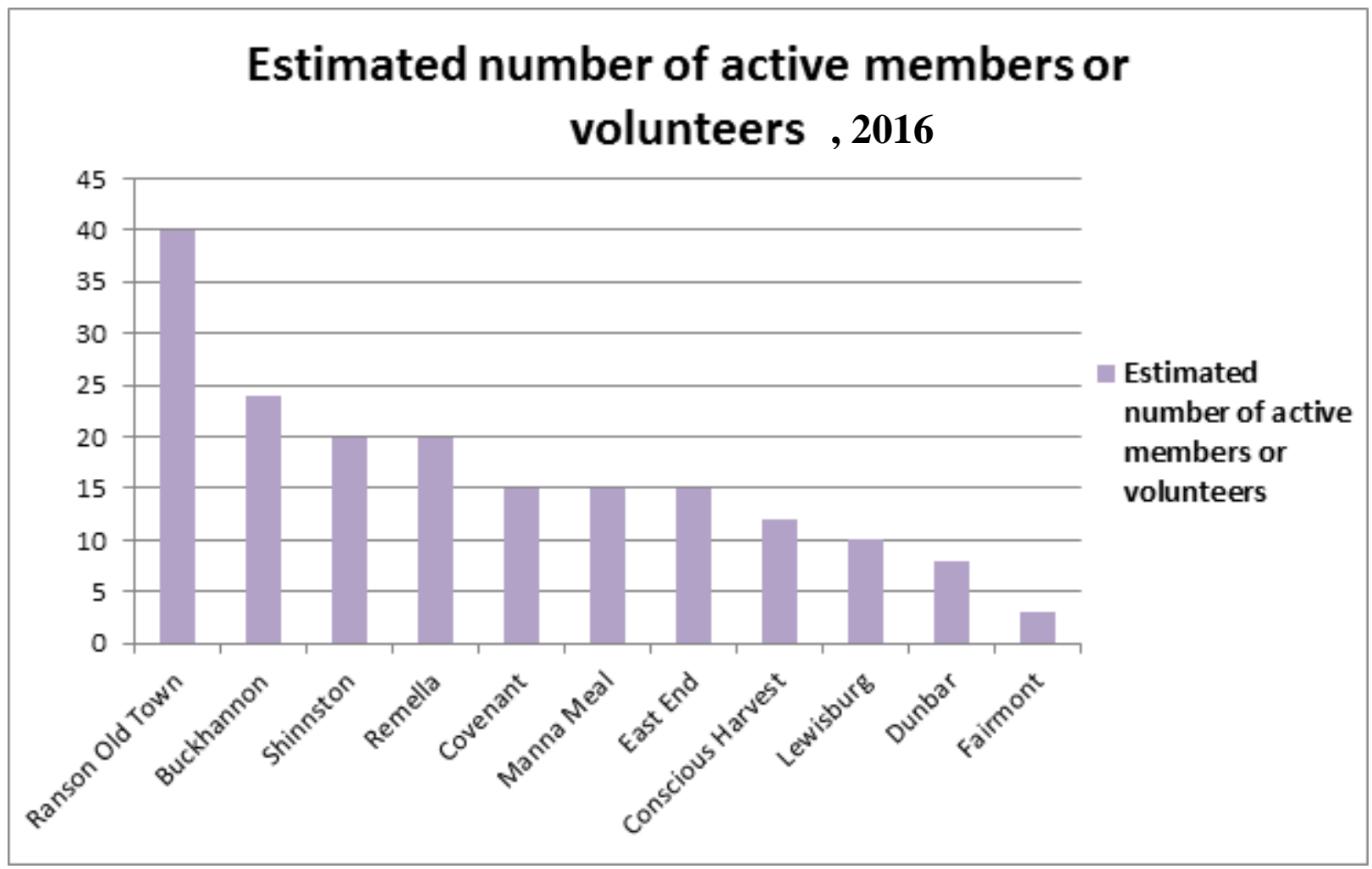

Five $(45 \%)$ of the gardens I interviewed had a contract, and 4 of them said the contracts were useful because it helps organize the garden, set responsibilities, make the gardener committed to their bed/plot or else have a penalty, and it also helps keep track to the gardeners (who is a member this year and who was a member last year). The one leader that said it was not helpful said so because she was not fully enforcing the rules in the contract and found it hard to implement the rules and keep track of if they are being followed. Five (45\%) gardens had fees 
and all the leaders said that fees were useful because they can be used to pay for the garden's insurance, workshops, advertisement, supplies, water, compost, and/or seeds. Two of the 5 said the fees are enough to cover their costs, so 3 gardens still had costs to cover after the use of the fees. Also, none of the gardens knew of anyone who was not able to join the garden because of the fees. The leaders said that if anyone needed help paying they would reduce the fee, let them in for free, or pay their way themselves.

Most of the garden leaders that I interviewed became the leader of the gardens either because the garden was their idea, or because they volunteered to be the leader, or someone recommended them to become the leader. Most of the leaders were volunteers, with only one leader who was hired by the Health and Wellness center in Williamson, WV to lead the garden and other food projects after she worked with the garden as an AmeriCorps Volunteer. These leaders bring many skills to the garden, such as gardening experience, management skills, the ability to coordinate, organize, write grants, advertise, and network. When making decisions about the garden's management 3 of the 11 garden leaders make all decisions by themselves, while the other 8 leaders have a board, committee, or local group they speak with before making major decisions. These meeting are usually informal talks about the issues, and only one garden leader said that they have a formal voting system at their meetings. From a Conscious Harvest board meeting that I observed, I saw how members of the board followed after the topics brought up by the leader and issues were discussed casually, with people adding in their own concerns and goals as the meeting went on. Each person had their own plans and goals for the upcoming summer, from getting more supplies, to planting experiments.

Garden leaders can provide multiple services for the garden. Some organize volunteer groups to come in and they lead the groups as they help in the garden. Some search for grants 
and donations for the garden, pay the bills, and collect the fees if the garden has a fee. Other garden leaders coordinate garden events, projects, and/or workshops. If someone needs help learning more about gardening or has questions, 8 of the garden leaders said they help provide members/volunteers with gardening knowledge. Either the gardener would come to the leader with questions or the garden has a master gardener who helps answer questions, or the other members help each other. Most of the gardens have members who are helping each other by sharing the advice and gardening knowledge they have, and most of the garden leaders provide seeds or seedlings and/or gardening supplies for the members/volunteers of the garden.

The interviewees said that in the summer when the garden is active they visit the garden anywhere from daily to once a week. Only one leader said that she visits the garden twice a month and has a separate manager of the garden who goes every week. When they visit the garden they are usually there to upkeep the garden through weeding, planting, harvesting, leading volunteers, socializing with the members/volunteers, checking for damages, and checking the maintenance of the plots/beds. Many of the garden leaders garden in the garden themselves by having their own plot/bed or working communally with the other volunteers. Only one of the leaders I interviewed said that she did not garden in her community garden. The leaders main motivation for producing the food they are helping to grow, is either for the food to be given away to someone who needs it, or for the enjoyment of growing it for themselves. Five garden leaders said that their main motivation for growing the food is to give it to a food pantry, meals on wheels, and/or soup kitchen. The other 6 garden leaders are growing their food for the enjoyment, to learn something new, to cook with it, to supplement their grocery shopping, or to experiment with different plants and growing techniques.

Only one leader said that she does not have regular conversations with the active 
members of the garden. From my observations at Conscious Harvest I've seen how garden work days can be a way for garden leaders and gardeners to socialize more and help each other get more work done by utilizing their efforts. When a garden is able to have scheduled work days once a week the members are able to see

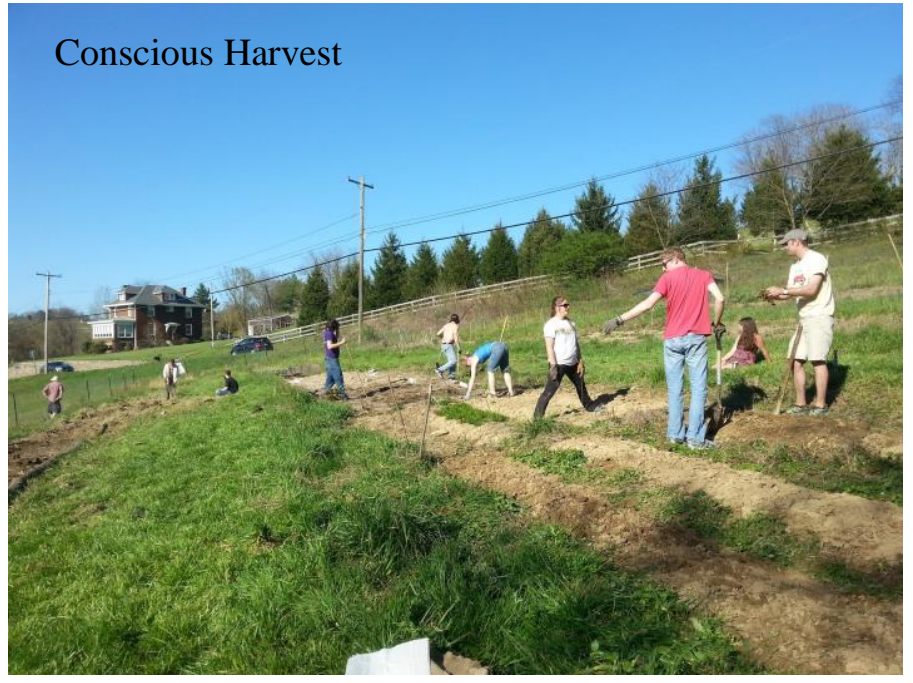
each other on a regular basis if they so wish, otherwise garden members who are working on their individual plots/beds may never see each other. A close relationship between the leader and the gardeners enables the leader to understand why the members chose to garden in their community garden. The four garden leaders that said they are motivated by feeding people and giving food away, also said that they believe their active members and volunteers share the same motivation. The other gardens believed the members were gardening there in order to learn something new, grow less expensive food, socialize, and have access to the land to grow on.

When asked what makes a good garden member/volunteer reliability and dedication came up the most. They want their gardeners to be enthusiastic and responsible. When asked what are the characteristics of a successful garden, 4 leaders talked about the maintenance of the garden. Soil conditions, access to water, grow as much as possible as long as possible, maintaining weeds, and growing a variety of food were all mentioned. From my participant observations I can attest to the issues leaders and gardeners have with weeding, and experimenting with planting techniques to decrease the amount of weeds. Gardeners not being 
dedicated and reliable leads to beds or plots filling up with weeds. Gardens that have participants that share knowledge and learn from each other, while being reliable and dedicated gardeners, are what the leaders saw as a successful garden.

Most of the gardens had no worries when it came to the security and access of the garden's land, water, and seeds. There were 4 (36\%) gardens that talked about issues they have had with land or water. One was the Ranson Old Town garden, which is on city licensed land, and they are worried the land could be taken away from them and they would not be able to do anything about it. Manna Meal also had land issues when they were first starting off. They asked for a bit of private property to start the garden on and was turned down without knowing why, until later when they saw that the land was turned into a parking lot. Being on privately owned land in their beginning days also limited who was allowed to come onto the land, since the owners did not like the idea of the people who came to eat at the pantry coming onto their property. Manna Meal also used to have to carry water in jugs to bring to the garden. Today they are on a new site where all these issues have been resolved. Dunbar garden also has to carry water in jugs and they said it is always in their minds that the city could sell the land they are on. Conscious Harvest is another garden that has fears that one day the private owner of the land they are on could decide to sell the land.

When asked if they saw themselves and the garden as being a part of a movement 8 said yes, that they felt like they were, and 3 said no. They all seemed to have different ideas about what the movement was for, based on their own goals and ideas about community gardens. They mentioned sustainability, socializing as a community, local food, food access, and educating people about growing food. The leaders' goals and visions for the garden and what it could provide for the community also varied, but the same themes always came up. They talked about 
feeding people who needed food, feeding and growing healthy food, and socializing with the community. In accordance with the leaders main goals for the garden, were their ideas about what they were providing through the garden (Graph E). All of the gardens said their garden is helping provide food for people who cannot afford healthy food, either through donations to pantries or offering beds/plots to low-income community members. Ten (90\%) gardens said that the garden was promoting healthier eating habits, $9(81 \%)$ gardens are trying to engage children in learning about food production and healthy eating, 8 (72\%) said their garden is helping provide food access to people who may not have had access to healthy food before, and 8 (72\%) said the garden was trying in engage in community development. Seven (63\%) said they are producing organic and chemical free food, 7 (63\%) were trying to educate all ages about food and growing food, 6 (54\%) said they are trying to help people be more self-sufficient, 6 (54\%) were trying to promote local food production, 6 (54\%) said that the garden is trying to provide people with more control over the production of their food, and 2 (18\%) said they are trying to provide a more sustainable way to produce food. 


\section{Graph E}

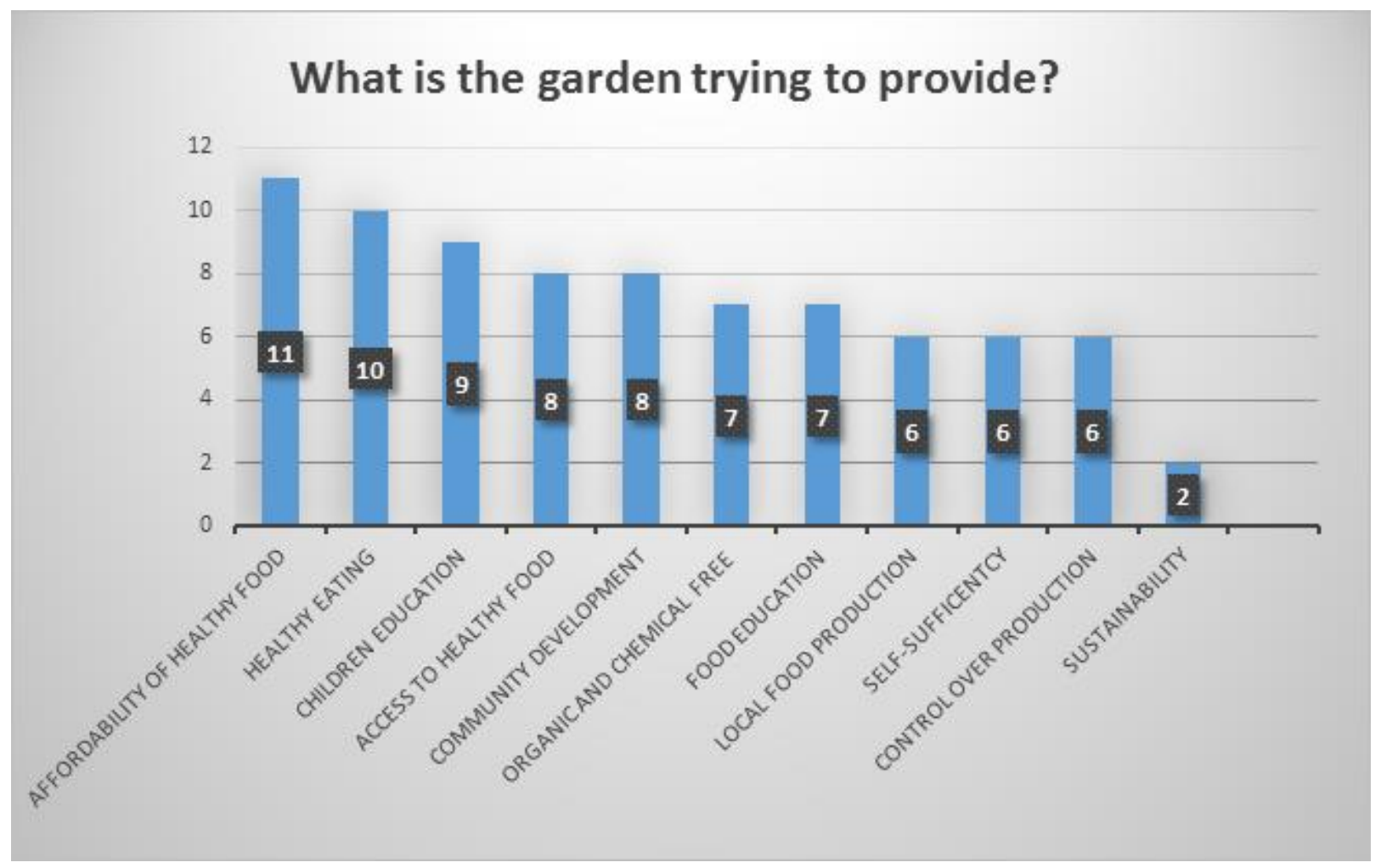

Over half of the leaders said that they see the food from the garden as being better than food from supermarkets because it is "fresh", chemical free, pesticide free, not processed, tastes better, and is more energy efficient. Although, none of the gardens are trying to make a political statement for change in the food system. The Conscious Harvest garden is the only garden I spoke with that is trying to use the garden as a way to talk about political issues within the food system, but not even Conscious Harvest has a clear statement for change that they want to see in the future. Most of the gardens are not trying to provide a space where the gardeners can exercise certain rights the leaders believe they should have. The leaders, for the most part, never used the idea of rights or language of rights to address the garden's benefits or goals. 


\section{Chapter 8: Analysis: Community Action}

Due to community gardening being a community action, it is able to bring the community together and promote new ways for people to work and learn from one another. Garden leaders and gardeners speak about coming together as a community to work together for a goal or vision. For several of the gardens, that goal is to grow food and give it to people who need it. It's about helping the food security in their area by trying to feed a hungry community by a community action. For some gardens the mission is simply to bring different people from different ages and backgrounds to come together and meet each other, for the prosperity and peace of the neighborhood. The leader of the Buckhannon Garden said that for him the garden is less about the food they grow and more about the social interactions between the gardeners and building relationships. Then, there are also gardens that wish to promote healthier eating by growing healthy vegetables and fruit for themselves and others. West Virginia is known for its health issues when it comes to obesity and eating habits. The communities have realized that not everyone can afford healthy food, or do not have adequate access to a healthy food diet due to food deserts, and having gardening as an option gives an opportunity for people to eat fresh food in a setting that also makes them able to receive outdoor exercise. Gardens like the Alderson and Remella Community Gardens were specifically chosen to be created in those neighborhoods because they are in a food desert.

Bringing the community members together enables them to learn new gardening skills from each other, and then share their knowledge with others. They are able to learn, share, and help each other, while meeting new people and keeping a connection with the garden leader. Most of the leaders said that they were helping gardeners garden if they are beginners, or had questions or concerns. Since the garden is a community action the people are not on their own to 
learn this new skill. They have the help of the leader who visits usually once a week in the summers, and they also have the other gardeners or local master gardeners. Although, some gardens are probably better at this than others, because some individual gardeners may garden on their own at the community garden and not see or speak to the other members. Whether the garden has work days, volunteers groups, or other such ways of bringing the members and volunteers together, will say as to how well a gardener will be able meet and learn from other members and volunteers. Most of the leaders did state that they see gardeners helping others gardeners, and so it would seem that they are able to work together.

Not only are they able to learn and help each other with their gardening techniques, but as a community action the garden is able to provide the gardeners with everything they would need to start their work. Most of the gardens were providing the gardeners with tools, seeds, water, and of course land. Some gardeners are gardening at the community garden because they do not have any land space at home to garden in, while others may be gardening at both places and the garden is able to give them more space that they do not have at home. Unlike gardening at home, where you would have to have a good amount of land space, seeds, tools, water, and the knowledge to know what to grow and how to grow, the community garden is able to provide you with support for all your gardening needs.

The highest challenge to this community action has been the lack of dedicated gardeners or volunteers, and lack of participation. This challenge is mentioned in previous literature, as well as how networks with organizations can help with this challenge (Mikulec et al. 2013, Ghose and Pettygrove 2014a). While organizations such as YouthWorks and Boy/Girl Scouts are able to help supply volunteers, even gardens that had organizations giving them aid, said that more participation or dedication was needed from the gardeners. The need for more volunteers, 
more labor, and more participation was the number one challenge shown in the survey. In the interviews the challenge was revealed again by the responses of what makes a good volunteer/member and successful garden. The leaders said that dedicated and reliable volunteers and members are a necessity. Why the demand and enthusiasm for the gardens is low could be from a variety of issues, like lack of advertisement, lack of a mission statement, or lack of a welcoming atmosphere. It is possible that people are not participating and joining the garden as much as they could be, because they do not have the confidence to try something they have never done before. Another reason is that people may think they do not have the time or energy to put into trying something that may fail the first time, or that they do not believe they are good at. No matter what the reasons are, the leaders can try to motivate people by telling them the benefits gardening can have and by giving them the confidence they need by having someone who can help them through the gardening process. Work days and workshops are ways to educate people in a fun way about the opportunities at the garden.

Gardeners that abandon their plots are possibly doing so because they did not prioritize their time well enough to schedule in the work it takes to keep up a bed or plot. The turnout at end of the year cleanups could be low because individual gardeners care more about their own bed or plot, than they do about helping the garden as a whole, when it comes to cleaning up and getting the garden ready for winter. The way leaders have been able to combat these issues has been to have a contract for the garden that the leader enforces, to keep the gardeners dedicated to their plots/beds and reliable to the garden. Having an enforced contract forces the gardener to make a decision that they will maintain their bed and be a part of the garden as a whole when work days are necessary. The Big Red Barn Community Garden's contract must be signed by the garden members, and it has rules that state, "I will not leave my plot unmaintained for any period 
of time exceed two weeks without making arrangements for its care", "Maintenance of my garden plot is my sole responsibility. I will water as need, remove weeds promptly, control disease or insect infestations, properly remove contaminated plants, and harvest produce in a timely manner", and "I will participate in regular cleanup and maintenance, as well as fall cleanup for the garden".

\section{A Movement}

Community Gardens have been appearing more and more across West Virginia. The garden leaders stated how they are seeing gardens gain popularity, and how they have become a "hot topic", as the leader of the Buckhannon garden stated. Eight of the gardens I surveyed were created between 2005 and 2012, and from 2013-2015 eleven were created. Fewer gardens started in the seven years before 2013, than the three years after. With more and more gardens popping up and joining in on this "movement", it brings up the question as to what this movement is for and what it revolves around. There is also a question as to what kind of a movement this is, whether it is a political movement like food sovereignty, or an apolitical movement that is mainly based on community action.

When the community garden leaders were asked if they saw themselves and their garden as being a part of a movement 3 said no and the other 8 said yes, but some yes replies were more passionate than others. By splitting up the yes replies into yes and maybe, I could see the differences in the leaders who replied "absolutely" or "definitely" vs. those who replied "I suppose so" or "in some ways". With these three replies, there were 3 who said no, 4 who said maybe, and 4 who said yes. The three leaders who said that they do not see themselves as being a part of a movement, did so for different reasons. The Fairmont garden leader said no probably 
because she is a part of the organization "Learning Options" which is a non-profit organization that focuses on hands on education. Her response showed how education was her main goal for the garden, because the organization that she works for has taken over the garden. Therefore, she saw the garden as being more connected with that organization, than with a community garden movement. Then, the leader of Covenant Garden said no because the garden is a church garden that donates all their food, and she connected the goal of the garden with the church's principles instead of a garden movement. She said the garden had less to do with a movement, because it was mainly based on "following Jesus" by trying to "show God's love". Finally, the Lewisburg Garden leader said that she did not connect her garden to a movement because the garden is not in a big city and is instead in a more rural area. She believed that garden movements in cities are the ones that are helping people have more food access and standing up for such issues. She called her garden more "selfish" because the gardeners are growing food for themselves and not giving it away. Although these were her thoughts, food access is being addressed in rural areas and not just large cities, so the garden movement does not have to be restricted to the cities. Even though she calls her garden selfish, the idea of growing food for yourself is still something that addresses control over food and is something that can make a garden able to connect with a movement, like food sovereignty.

When the leaders who said that they did feel connected to a movement were asked what the movement was for, their replies were quite different depending on the person. Two said the movement is for sustainability, two said it is for growing local food, two said it is for feeding hungry people, one said it is for community development, one said it is for healthy eating, and one said it is for education. These replies were all aspects of gardening that can be seen in leaders' goals for their gardens and what the gardens are trying to promote, but each person drew 
out a certain aspect over the others. When it comes to scaling up their views of their garden in relation to other gardens in the state or across the country, they do not agree on what the gardening movement is about. This could be because the movement is about many different things and can address multiple issues at the same time.

If there is not an agreeance on what the movement is for then it is possible this is because the gardens are not well connected to one another under a certain mission statement. Community gardens across the state do not communicate with each other and have no real connection keeping them in contact. They are also usually not connected to any garden campaigns or organizations that are nationwide. This means that they do not have a unifying mission statement or procedure to follow, as more organized movements do. Several of the leaders replied yes to the movement question, so they feel connected to something, but they may not know what exactly they are connecting with. If this is the case then it is hard to say that they are a movement at all, but the action is growing across the state and people are joining in. The reason for the different views of the movement could also be because of the different ways garden leaders frame their gardens and their gardens' mission.

\section{Framing}

"Framing" or a collective action frame, is "constructed by movement organizers to attract supporters, signal their intentions, and gain media attention" (Tarrow 2006). Garden leaders tend to frame their gardens in slightly different ways depending on the garden and the leader. While the Buckhannon leader said that his garden is mainly focused on getting the community to socialize, Shinnston and Manna Meal are more focused on feeding people through their pantries, and gardens like East End say their main goal is about letting people eat healthier. A leader and 
garden's main goals and promotions are what is able to frame the garden and attract gardeners.

Whether they are framing the garden as being good as a socializing, feeding, or health action, the leaders are able to attract gardeners and volunteers by these frames, which show why the garden is important and useful.

When the leaders named their own goals for their gardens, the goal for their garden sometimes was also mentioned as what they saw the community garden movement being about. Manna Meal said their goal, and therefore their frame for their garden, was feeding people who need food, and she also mentioned feeding people healthy food as being what the movement is about. The leader of Manna Meal said her vision for the garden was to, "fill all the food pantries in our valley with fresh products on weekly basis." After being asked if she saw her garden as being a part of a movement, the leader of Manna Meal said,

"Without a doubt. We have to drink water, we have to eat, and I think that we are finally coming to the realization of how we need to eat, and that we need to eat fresh food. So I do believe it is a movement. I mean when I was in my 20's, I was basically a hippie, and we believed that way then, and so my life has been living that way. Eating fresh food, not trying to eat as much meat, trying to put a fresh product in my body instead of processed food."

This leader was able to express her desire for community gardening to be a movement, and a movement that incorporates a frame for eating fresh healthy food. She went so far as to say, "I pray it is a movement."

Other gardens changed their ideas for what the movement is for, vs. their framing of their garden. Ranson Old Town Gardens' leader said that his goal and frame for the garden is about getting the community to come together to learn, share, and help each other, while he saw the movement being about sustainability. Only two garden leaders stated that they see the movement as being about sustainability. The leader of the Ranson Old Town Gardens said that community 
gardening is a way to have a "sustainable" connection with the environment. That it is "green" and brings about a "harmonious relationship with the environment and each other". Seeing climate change as a major issue society is facing today, he saw gardening as a way to create an environmentally positive change.

The leader of the Dunbar garden also had strong beliefs in gardens effects on sustainability, and therefore shared a similar framing of her garden. When asked what this movement is for, she had this to say:

"Sustainability. I think the Victory Gardens of World War II are something we have to hold on to. Especially in West Virginia. We need to promote agriculture in $\mathrm{WV}$, even if it's just urban gardens, we need to promote that. We need to all be more self-sustaining. I volunteered this morning at our community food bank and it's a little pantry, it's not big, but it's sad when people find it easier to come in and put their hands out and let someone else feed them, than it is for someone to raise their own produce. I just think we have to teach that. We cannot continue to teach people to be dependent on someone else. Many of the people who come to our food pantry are perfectly capable of raising a garden."

She related community gardening to the Victory Gardens of WWII and believed the war gardens' message of being self-sustaining was something that could be used and promoted today. While the Ranson leader was focused on environmental sustainability, the Dunbar leader focused on sustainability by being self-sustaining as a way to be less reliant on others. These views are a way of seeing gardening sustainability as a way to fight against a climate crisis or economic crisis.

Framing also shows itself in how the leaders described what their gardens were trying to promote. The leaders were asked about a variety of aspects that community gardens can incorporate and promote through the garden. The questions were separated into three different categories which represent three different frames garden leaders were using when talking about 
their garden. A garden leader could use one, two, or all three of the frames. The first two questions were about whether the garden was trying to provide better food access to those who did not have adequate access to healthy food before, and/or were they trying to provide food for people who could not afford healthy food. These two questions make up category/frame 1, which is based on feeding people who need access to healthy food (Table B). The next 4 questions asked about promoting community development, healthy eating, education on growing food, and engaging children in food production and healthy eating education. These questions make up category/frame 2, which is based on education, community, and health. The last 5 questions asked if they were trying to promote local food production, provide environmentally safe organic and chemical free food, provide a more sustainable way of producing food, trying to let people be more self-sufficient, and/or trying to provide more control over the production of food. These questions are a part of category/frame 3, which is based on sustainability, control, and environmental care.

\section{Table B}

\begin{tabular}{|c|c|c|}
\hline $\begin{array}{l}\text { Category } 1 \text { representing } \\
\text { Frame 1: Feeding the Hungry }\end{array}$ & $\begin{array}{l}\text { Category } 2 \text { representing } \\
\text { Frame } 2 \text { : Education, } \\
\text { Community, and Health }\end{array}$ & $\begin{array}{c}\text { Category } 3 \text { representing } \\
\text { Frame 3: Sustainability, } \\
\text { Control, and Environmental } \\
\text { Care }\end{array}$ \\
\hline Better access to food & Community development & Local food production \\
\hline \multirow[t]{4}{*}{$\begin{array}{l}\text { Helping those who cannot } \\
\text { afford food }\end{array}$} & Healthy eating & $\begin{array}{l}\text { Organic and chemical free } \\
\text { food }\end{array}$ \\
\hline & Education & Sustainability \\
\hline & Children & Self-sufficiency \\
\hline & & Control over food production \\
\hline
\end{tabular}


Frame 1 and 2 were quite common among the gardens. All the gardens answered yes to at least one question from category 1 and two questions from category 2 . Frame 1 was very common among the gardens and it is well known in literature that gardening is trying to address food access barriers (Fairbairn 2012, Shawki 2012, Block et al. 2012). On the other hand, there has not been a presence of research on community gardens in rural areas growing and giving away food to pantries and soup kitchens. Frame 2 is a frame that most community garden literature references. Community garden research is well aware of the presence of education, community, and health as aspects of gardening (Larder et al. 2014, Ghose and Pettygrove 2014b, Corrigan 2011, Draper and Freedman 2010, Armstrong 2000). Category 3 on the other hand, ranged from 0 to all 5 questions with a yes reply. Control, sustainability, and environmental care are rarely, if ever, spoken about in community gardening literature.

Category 3 had 0 of the 5 questions answered yes to by three gardens, 1 yes by one garden, 2 yeses by one garden, 3 by two gardens, 4 questions answered by two gardens, and all 5 answered by two gardens. All of the gardens that said a full yes, to being a part of a movement were a part of frame 3, with at least 3 questions answered yes to. A garden that said no to being a movement and one that said maybe, were also a part of category 3's frame, with 4 questions answered yes. The only two gardens that answered yes to all 5 of category 3's questions were also the two gardens that said the garden movement is for sustainability, Ranson Old Town and Dunbar. From this I can only conclude that the gardens that felt a part of a movement were more likely to promote a category 3 frame, but not always. Also, believing the movement is for sustainability put Ranson Old Town and Dunbar in a full category 3 frame. 


\section{Political/Apolitical}

Category 1, 2, and 3 could be seen as being on a gradient that goes from the least politicized questions to the more politicized questions that aligned the garden closer with the food sovereignty movement. What is seen as being political can be complicated and hard to define, but for my research I looked at political gardening as being about political rights and wanting a change in the establishment of the capitalist food regime. Countries around the world are fighting for their rights, and change in the agriculture field, and they are using the food sovereignty movement to do so. I compare this want for political change and right to control over food, to the community gardens I spoke with. Frame 1 can be either political or apolitical, depending on the leader's reasoning and approach to gardening. For the most part the gardens are using frame 1 as a way to address the issue of hunger through community action, without asking for governmental rights or political change. Frame 2 is based around community action, and is therefore more apolitical and does not ask for change to the food regime. Frame 3 is the most political view point, because it addresses a need for change, and a change that could be created by government interference. Some garden leaders would like to see a change in how food is being grown, eaten, and used. Some gardens said that the transportation of food is not energy efficient, some addressed how wasteful we have become with food, and others fear chemical and pesticide usage on produce.

The category 3 frame is rarer than the others possibly because other garden leaders did not see a "crisis" coming from the category 3 issues. Garden leaders like the Ranson and Dunbar leaders believe there is a sustainability crisis, an environmental crisis, and a food control crisis. This idea of a crisis is what motivates people to want change. The practice of gardening is highest during a crisis. WWI and WWII gardening, and Arthurdale during the Great Depression, 
were acts of sustainability, self-sufficiency, and control during a time of crisis. When people see or feel a crisis they react, while others may not feel it or believe it exists. The garden leaders that did not try to promote sustainability or control over food production were the ones that did not see those issues as being a part of a crisis, or see it as necessary. They are more motivated by their own category 1 or category 2 frames, therefore their crisis, or what was seen as more necessary to attend to, had to do with food security, community, and health.

The gardens that had more of a category 3 framing for their gardens were the ones who wanted to address environmental, sustainable, self-sufficiency, and control over food issues. These are all political issues that are closely allied with the food sovereignty movement. While these garden leaders were the most political in their responses, garden leaders are not trying to create political change, like food sovereignty. Food sovereignty would wish to overthrow the private corporate food system and start again with local agriculture, which they believe will create sustainable food security for all communities. On the other hand, even the most political thinking garden leaders believe community action can address food security, not political change to the food regime. The leader of the Ranson Old Town gardens said,

"We have government action. I would like to see the community based action become more important." "Everybody in our county should have enough to eat and hopefully healthful. We should not have anybody on the streets begging for food... They at least have a right to having a warm place and hot meal, having enough food to eat, and hopefully healthful food, but not every community can provide that, but that is more of a community support responsibility." "We are trying to address that. That's our goal. That's one of our goals."

This garden leader had a political mind set and wanted change in how people are being fed. When asked about people's right to food, he agreed that people should have healthy food, but instead of demanding that right from the government, like food sovereignty would, he placed the burden on himself and the garden, as a community action. 
The community garden movement in West Virginia is an apolitical movement, based mainly on community action. The leaders of the garden had negative feelings toward the idea of politics and seeing its role in the food system, and its role in changing the food system. A couple gardens said politics is too "polarizing". The Ranson leader said "We try to stay clear of that." Others didn't see what politics had to do with their garden. It is possible they were reacting mostly to the word "political" and seeing the word as meaning nothing more than voting elections. Going even further, most of the leaders said they were not trying to make a political statement through the garden or trying to create political change in the food system. Ranson leader said he did not feel like he could be triumphant in a political change stance, and Manna Meal leader stated she did not know how she could create a change. Trying to change the political food regime is something leaders do not know how to do, where to start, or if it would be worth it in the end. So instead, they take the burden on themselves, and do what they know how to do.

When it comes to using rights to fight for land, water, seeds, and control, garden leaders are not engaging with that kind of language. Mostly leaders do not have a reason to, because most of the gardens have no issues with getting access to water and seeds. Some worry about their land, and how it could be taken from them, but others do not, because they would then just try and find another spot of land. Finding land in the rural county is not as hard as it is in the larger cities, where gardens have to fight for land. These gardeners can also easily take control of their food production with the use of the garden, in the summer time, and if more gardens start high tunnels, then they could garden year round. 
While these gardens may be apolitical, and therefore less aligned with radicalism of the food sovereignty movement, that does not mean they are not able to do great things. They are putting hard work into improving their communities anyway they know how. The garden leaders care about the people around them, and volunteers and gardeners are able to share their care for others by helping the gardens. The leaders are taking ahold of the issues they care the most about and framing their garden in order to address their concerns. These gardens are also able to use food sovereignty to have control over what they see their community needing.

\section{Food Sovereignty}

Food Sovereignty enables a person to have more control over their food, from the way it was produced to who is able to consume it. The Food Sovereignty movement has been using this control to try and create radical political change for the betterment of food security and food sustainability, and for the lives of peasant farmers around the world. Community Gardening in WV has been using food sovereignty as a way to help communities have more control over their food security, while also having control over the health of the food and their own health. Pantry gardens, church gardens, and multi gardens that are giving away food to charities are using food sovereignty as a way to grow food inexpensively and share that food with the people who need it the most. Manna Meal started their garden because they wanted to have a way to supply affordable healthy food to their food pantry. This is a way for people as a community to come together in order to try and manage their own community's food insecurity. The control over food that food sovereignty gives them, gives them control over their own community's food security and health.

Individual gardens are able to offer affordable food options to low-income or food desert 
communities by offering a garden plot, and in this way they are taking more control over the food security of the community. The Covenant Garden leader stated that people in the neighborhood were not being paid enough and were "working poor". In response the garden tries to help people who are a part of the working poor and they offer employment for veterans to work in the garden's high tunnel. Also, the Remella Garden is across from a low-income housing facility and can be there as an opportunity for the housing members to grow affordable food.

Garden leaders stated how the benefit of gardening is the way you can know how the food was grown from "seed to consumption", as the leader of the Dunbar garden stated. This is not food that comes from an unknown location and grown by unknown techniques. Gardening is a way to reconnect with the production of your food. The leader of the Conscious Harvest Garden said that he likes the food he grows better than supermarket food because, he stated "I see my labor in it". Other garden leaders also said they like the food from the garden better than traditional supermarket food, because they see it as "fresh", they believe it tastes better, and they know if pesticides or chemicals were used on the food. The leader of Manna Meal stated that she does not approve of processed food or the use of chemicals when growing food. She told me several times that she did not "trust the federal government". Since the government once said that cigarettes were not bad for you, she does not trust what the government says is healthy or not healthy, when it comes to processed food and GMOs. With this distrust in the food system, gardening is a way to have trustworthy food, in terms of its effect on your health. If you see your labor in the food you grow, you can have a more safe feeling about the health of the food, and its effect on your own health and the health of others. Food sovereignty leads to control over the health of the food, and the health of the people who consume it.

Several gardens are trying to engage people and especially children in eating healthier, by 
teaching them more about fruit and vegetables. They believe that by reaching children they can help the health of the state and cut down on health issues such as obesity and cancer. School gardening is happening across the state, and teachers are trying to incorporate school curriculum into gardening. Panels on gardening lessons for children were held at the 2016 TryThisWV conference. Gardens are teaching children and adults about different varieties of vegetables that they may never see at a supermarket, or may not have access to. Supermarkets only put forward food options that they believe will sell well. This means that more common kinds of vegetables and fruit are stocked, and the average person may never know about the vast varieties of vegetables and fruit they could be eating. In this way, through gardening you can try new things that you may have never eaten before, and this gives you a vaster array of nutrients.

The U.S. based Food Sovereignty movement has been helping community food security by empowering communities that suffer from injustices within their food system (Shawki 2012). The community gardens in WV have been contributing to this empowerment. It is also a part of the Food Sovereignty movement's definition to care about the production of food and have a right to healthy food (La Via Campesina 2016). WV gardens can be seen as using their right to healthy food by taking back control over the production of the food they are growing.

\section{Chapter 9: Overview, Further Research, and Limitations}

I was able to address and answer both of my research questions through the methods I used. Community gardening in WV is contributing to food sovereignty by how it is providing a space for community based agriculture and locally sourced food that is controlled by the gardener. The gardeners are able to learn and share their local knowledge, while exercising control over the production of their food. Some gardens are trying to use food sovereignty to provide a more sustainable way to help the food security and injustices in their community. The 
garden is able to provide them with land, water, seeds, and knowledge, so that they can exercise a right to garden.

Community garden leaders in WV are trying to promote food sovereignty for its effects on food security, health, and community development. While the leaders are promoting some of the same basic elements of the food sovereignty movement, they are not trying to create political change like the movement promotes. Instead of demanding change from the government, they are trying to change the lives of the people in the community by their own actions. They are not demanding certain rights from the government, such as the right to food. Most gardeners would not go so far as to be the kind of anti-capitalism, anti-neoliberalism activist that the food sovereignty movement calls for, but they do have the ability to make positive impacts on their communities.

“Community gardening represents an emerging field of research brimming with opportunity for active collaboration among researchers, practitioners, and community members" (Okvat and Zautra 2011, 383). Future research could further my study in order to incorporate the topics of analysis I was not able to address. Since I only spoke with garden leaders I was not able to speak with the gardeners from each of the gardens. If further research was able to speak with the gardeners of WV, questions about how gender, race, and economic status of the leaders and gardeners could be compared and used to understand how these factors my influence the understanding and use of food sovereignty. I was not able to see if gender, race, or economic status would affect a person's views of the politics behind gardening or the use of the gardens' frames. Gardeners would be able to give a different understanding of how the garden operates vs. what the leaders says. While a leader may say the garden is following a certain frame, the gardeners may express a different frame being used. Gardeners could also explain what 
challenges they face when participating in the garden and if they feel like the garden is being well managed. Gardeners would be able to show their feelings about the garden leader and what makes an effective leader. Gardeners can also explain why they chose to be a part of the garden or volunteer at the garden and the motivations of gardeners could be studied.

Further research could also go further into the food insecurity of the communities where community gardens are located. Further research could cover how much and to what extent community gardens are able to contribute to the food security aid of their neighborhoods. How much produce can a garden source for a pantry? What percentage of a pantry's food comes from a garden? How much of what gardeners eat comes from their garden plot? These questions would be able to help show to what extent community gardens are able to help a pantry or individual person be more sustainable and self-sufficient. Research into community gardening is a way to further the geographic literature on food security and food sovereignty by the use of gardening.

My research was limited by not speaking to gardeners and volunteers, and by focusing on food sovereignty instead of food security or other issues. I also only spoke with leaders from gardens I could find through internet searches and there could be more that are not being advertised online. Furthermore, I only spoke with leaders inside WV and more research could compare WV gardens to those of an urban city or another rural state or town. 


\section{Bibliography}

Alkon, Alison Hope, and Teresa Marie Mares. "Food sovereignty in US food movements: radical visions and neoliberal constraints." Agriculture and Human Values 29, no. 3 (2012): 347-359.

Armstrong, Donna. "A survey of community gardens in upstate New York: Implications for health promotion and community development." Health \& place 6, no. 4 (2000): 319-327.

Arthurdale Heritage Inc. Accessed May 2016. https://arthurdaleheritage.org/history/.

Ariza, Fabio Alberto Pachon. 2013. "Food sovereignty and rural development: Beyond food security." Agronomía Colombiana 31 (3): 362.

Bini, Valerio. "Food security and food sovereignty in West Africa." African Geographical Review (2016): 1-15.

Block, Daniel R, Noel Chávez, Erika Allen, and Dinah Ramirez. 2012. "Food sovereignty, urban food access, and food activism: contemplating the connections through examples from Chicago". Agriculture and Human Values. 29 (2): 203-215.

Boone, Karie, and Peter Leigh Taylor. "Deconstructing homegardens: food security and sovereignty in northern Nicaragua." Agriculture and Human Values 33, no. 2 (2016): 239-255.

Burnett, Kim. "Trouble in the Fields: Fair Trade and Food Sovereignty Responses to Governance Opportunities After the Food Crisis." Geopolitics 19, no. 2 (2014): 351-376.

Blay-Palmer, Alison, and Betsy Donald. "A tale of three tomatoes: The new food economy in Toronto, Canada." Economic Geography 82, no. 4 (2006): 383-399.

Cid Aguayo, Beatriz, and Alex Latta. "Agro-ecology and food sovereignty movements in Chile: sociospatial practices for alternative peasant futures." Annals of the Association of American Geographers 105, no. 2 (2015): 397-406.

Clendenning, Jessica, Wolfram H. Dressler, and Carol Richards. 2016. "Food justice or food sovereignty? Understanding the rise of urban food movements in the USA". Agriculture and Human Values. 33 (1): $165-177$.

Cockburn, Jenny. "Bolivia's Food Sovereignty \& Agrobiodiversity: Undermining the Local to Strengthen the State?." Theory in Action 7, no. 4 (2014): 67.

Corrigan, Michelle P. "Growing what you eat: Developing community gardens in Baltimore, Maryland." Applied Geography 31, no. 4 (2011): 1232-1241.

Crossfield P. 2011. "Venezuela's radical food experiment: Seeking 'food sovereignty,' Chávez puts oil wealth toward a local, sustainable food system". Nation. 293 (14): 32-34.

Draper, Carrie, and Darcy Freedman. "Review and analysis of the benefits, purposes, and motivations associated with community gardening in the United States." Journal of Community Practice 18, no. 4 (2010): $458-492$.

Fairbairn, Madeleine. 2012. "Framing transformation: the counter-hegemonic potential of food sovereignty in the US context". Agriculture and Human Values. 29 (2): 217-230.

Food Research and Action Center, "How Hungry is America?" FRAC's National, State and Local Index of Food Hardship (2015).

Ghose, Rina, and Margaret Pettygrove. "Actors and networks in urban community garden development." Geoforum 53 (2014a): 93-103. 
Ghose, Rina, and Margaret Pettygrove. "Urban community gardens as spaces of citizenship." Antipode 46, no. 4 (2014b): 1092-1112.

Goodman, David, and Michael Goodman. "Alternative food networks." International encyclopedia of human geography 3 (2009): 208-220.

Gowdy-Wygant, Cecilia. Cultivating Victory: The Women's Land Army and the Victory Garden Moment. Pittsburg: University of Pittsburg Press, 2013.

Hayden-Smith, Rose. Sowing the Seeds of Victory: American Gardening Programs of World War I. McFarland, 2014, kindle edition.

Hopma, Justa, and Michael Woods. "Political geographies of 'food security' and 'food sovereignty'." Geography Compass 8, no. 11 (2014): 773-784.

Jarosz, Lucy. "Comparing food security and food sovereignty discourses." Dialogues in Human Geography 4, no. 2 (2014): 168-181.

Kurtz, Hilda E. "Scaling Food Sovereignty: Biopolitics and the struggle for local control of farm food in rural Maine." Annals of the Association of American Geographers 105, no. 4 (2015): 859-873.

Larder, Nicolette, Kristen Lyons, and Geoff Woolcock. 2014. "Enacting food sovereignty: values and meanings in the act of domestic food production in urban Australia". Local Environment. 19 (1): 56-76.

La Via Campesina. "Organisation." February 9, 2011. Accessed September 20, 2016. https://viacampesina.org/en/index.php/organisation-mainmenu-44.

Leitgeb, Friedrich, Sarah Schneider, and Christian R. Vogl. 2016. "Increasing food sovereignty with urban agriculture in Cuba". Agriculture and Human Values : Journal of the Agriculture, Food, and Human Values Society. 33 (2): 415-426.

Louis, Elizabeth. "We Plant Only Cotton to Maximize Our Earnings": The Paradox of Food Sovereignty in Rural Telengana, India." The Professional Geographer 67, no. 4 (2015): 586-594.

McCarthy, James. "Rural geography: alternative rural economies-the search for alterity in forests, fisheries, food, and fair trade." Progress in Human Geography 30, no. 6 (2006): 803-811.

Mikulec, Philip, Alan P. Diduck, Beverly Froese, Heather Unger, and Kathryn MacKenzie. "Legal and policy barriers to community gardening in Winnipeg, Canada." Canadian Journal of Urban Research 22, no. 2 (2013): 69.

Murtagh, Aisling. "A quiet revolution? Beneath the surface of Ireland's alternative food initiatives." Irish Geography 43, no. 2 (2010): 149-159.

Okvat, Heather A., and Alex J. Zautra. "Community gardening: A parsimonious path to individual, community, and environmental resilience." American journal of community psychology 47, no. 3-4 (2011): 374-387.

Ohmer, Mary L., Pamela Meadowcroft, Kate Freed, and Ericka Lewis. "Community gardening and community development: Individual, social and community benefits of a community conservation program." Journal of Community Practice 17, no. 4 (2009): 377-399.

Partridge, Tristan. 2016. "Water Justice and Food Sovereignty in Cotopaxi, Ecuador". Environmental Justice. 9 (2): 49-52.

Pine, Adam, and John Bennett. "Food access and food deserts: the diverse methods that residents of a neighborhood in Duluth, Minnesota use to provision themselves." Community Development 45, no. 4 (2014): 317-336. 
"Rice Land Grabs Undermine Food Sovereignty in Africa". 2011. Development. 54 (1): 31-34.

Rigby, Samantha, Angela F. Leone, Hwahwan Kim, Connie Betterley, Mary Ann Johnson, Hilda Kurtz, and Jung Sun Lee. "Food deserts in Leon County, FL: disparate distribution of Supplemental Nutrition Assistance Programaccepting stores by neighborhood characteristics." Journal of nutrition education and behavior 44, no. 6 (2012): $539-547$.

Rudolph, Karlah Rae, and Stephane M. McLachlan. "Seeking Indigenous food sovereignty: origins of and responses to the food crisis in northern Manitoba, Canada." Local Environment 18, no. 9 (2013): 1079-1098.

Schupp, Justin L., and Jeff S. Sharp. "Exploring the social bases of home gardening." Agriculture and Human Values 29, no. 1 (2012): 93-105.

Shawki, Noha, and H. Renting. "The 2008 food crisis as a critical event for the food sovereignty and food justice movements." International Journal of Sociology of Agriculture and Food 19, no. 3 (2012): 423-444.

Shrestha, Pitambar, Ronnie Vernooy, and Pashupati Chaudhary. "Community Seed Banks in Nepal: Past, Present, Future." In Proceedings of a National Workshop, Pokhara, Nepal, vol. 1415. 2012.

Smoyer-Tomic, Karen E., John C. Spence, and Carl Amrhein. "Food deserts in the prairies? Supermarket accessibility and neighborhood need in Edmonton, Canada*." The Professional Geographer 58, no. 3 (2006): 307 326.

Sonnino, Roberta, and Terry Marsden. "Beyond the divide: rethinking relationships between alternative and conventional food networks in Europe." Journal of economic geography 6, no. 2 (2006): 181-199.

Stoll, Steven. 2014. "The captured garden: The political ecology of subsistence under capitalism". International Labor and Working Class History 85.

Tarrow, Sidney. The New Transnational Activism. New York: Cambridge University Press, 2006.

Turner, Bethaney, Joanna Henryks, and David Pearson. "Community gardens: sustainability, health and inclusion in the city." Local Environment 16, no. 6 (2011): 489-492.

US Food Sovereignty Alliance. Accessed September 20, 2016. http://usfoodsovereigntyalliance.org/what-is-foodsovereignty/.

Watts, David CH, Brian Ilbery, and Damian Maye. "Making reconnections in agro-food geography: alternative systems of food provision." Progress in human geography 29, no. 1 (2005): 22-40.

Way, Twigs. The Wartime Garden: Digging for Victory. Oxford: Shire Publications, 2015.

Weiss, Robert S. Learning From Strangers. New York: The Free Press, 1994.

WV FOODLINK. Wilson, Bradley, et al. "Nourishing Networks: West Virginia Community Security Assessment." WV FOODLINK. 2016. Accessed September 20, 2016. http://foodlink.wvu.edu/.

Wight, R. Alan, and Jennifer Killham. "Food mapping: a psychogeographical method for raising food consciousness." Journal of Geography in Higher Education 38, no. 2 (2014): 314-321.

Windfuhr, Michael, and Jennie Jonsén. "Food Sovereignty." Towards democracy in localized food systems. ITDG Edition, Rugby (2005).

Wittman, Hannah, Annette Desmarais, and Nettie Wiebe. "The origins and potential of food sovereignty." Food sovereignty: Reconnecting food, nature and community (2010): 1-14. 


\section{Appendix A:}

\section{West Virginia Community Garden Survey \\ Mary Ryan, Geography student, WVU, WV FOODLINK}

\section{Research Explanation and Consent}

WV FOODLINK is a research initiative of the Food Justice Laboratory housed in the Department of Geology and Geography at West Virginia University. With the support of our community partners we are developing a resource hub and learning commons to support a people-centered, resilient food network in Appalachia. For more details please refer to our website http://foodlink.wvu.edu/ This survey will provide data that will be used for the Master's Thesis of Mary Ryan, a Geography student at WVU. The data will also provide WV FOODLINK with ability to connect people to community gardens through their online database. Your comments will be kept confidential and you are welcome not to answer any of the questions.

If you have any questions about this survey, or how the data will be used and represented please don't hesitate to contact Mary Ryan at (304) 573-4242, mryan4@mix.wvu.edu.

We look forward to learning from you!

- $\quad$ Do you give your consent for the information you give to be used for research purposes?

Your name and identifiable information about yourself will not be made public.

- $\quad$ May we list your garden and the data you provide on the WV FOODLINK search?

The garden's contact information and the location of the garden will be shared on the WV FOODLINK website.

\section{Garden Contact}

- Who is the primary contact for this garden?

- Contact's title?

- Contact's phone number?

- Contact's email address?

Name and Location of Garden

- What is the name of the community garden?

- What year was the garden founded?

- Physical Address?

- City?

- County?

- If you were explaining to a friend how to get there how would you describe the location of the garden using things such as landmarks and other businesses?

\section{Garden's History}

- Which people and/or institutions were responsible for the formation of this garden?

- Why was the garden created?

\section{Type of Garden}

What process happened in order for the garden to be created?

- Is the garden a co-op?

- Which does the garden use?

o Raised beds 


\section{Garden Support}

Hydroponics

Aquaponics

Traditional ground gardening with plots

- What is the garden growing?

o Veggies

o $\quad$ Flowers

o $\quad$ Fruit

o Herbs

o Other

- Where does your financial support come from?

- What organizations help supply volunteers or other aid for the garden?

- How many volunteers help with the garden and do not own a plot or bed?

\section{Garden Organization}

- Number of plots/beds used by participants for growing food for themselves?

- $\quad$ Size of the plots/beds used by participants for growing food for themselves?

- How many people use the plots/beds for growing food for themselves?

- Who decides a plot's or bed's assignment to a community member?

- How in demand are your individual plots/beds?

- Low demand

- Supply meets demand

o High demand

- High demand and we have a wait list

- $\quad$ Do the participants have to pay for a plots or bed in the garden in order to grow food for themselves?

- $\quad$ Number of plots/beds used by participants for growing food not for themselves?

- $\quad$ Size of the plots/beds used for growing food not for the consumption of the participants?

- $\quad$ For whom is the food being grown in the plots/beds that are not for the consumption of the participants? (a food pantry, local families in need, etc.)

- How many participants work in the plots/beds used for growing food not for the consumption of the participants?

\section{Cost of a Plot or Bed}

- How much does a plot or bed cost?

- What is the money used for?

- Who decides the price of a plot/bed?

\section{Use of the Garden}

- $\quad$ Are there any restrictions on who can be a part of the garden? If so, list restrictions.

- Does the garden have plots or beds specifically for...

o Children

o Veterans

- Members with disability

o Other

- $\quad$ Does the garden hold work days? If so, when and what time?

- Is the garden fenced or gated, and if so, for what reason? 
- Has your soil been tested?

- Do you allow GMO seeds to be used in the garden?

- Where do you get your seeds for the garden?

- $\quad$ Do you have any issues with getting the kinds of seeds you want?

- Do you allow chemicals to be used in the garden?

- How do you receive your water supply?

- $\quad$ Is the garden on public or privately owned land?

- Who owns the land? Can the land be taken away by the owner? Explain.

- $\quad$ Do you have a contract with the land owner?

- Is the garden required to have liability insurance?

- Does the garden have communal plots or beds that gives to food pantries? If so, name the pantries.

- $\quad$ Any other kind of food security aid given through the garden? (sharing produce with schools, nursing homes, charity donations, etc.)

\section{Garden Contracts}

- Does the garden have a contract that the gardeners must fill out to receive a plot?

- What kind of rules must the gardeners abide by?

- Who created the contract rules?

\section{Benefits and Barriers}

- Were there obstacles or barriers that had to be dealt with, or is still being dealt with, in the formation and upkeep of the garden?

- What are the benefits of this garden?

- How would you like the garden to look in the future? What are your future goals?

\section{Thank You}

Any additional information that you would like to share?

Thank you so much for taking the time to fill out this survey. 


\section{Appendix B:}

\section{Interview Questions}

1. How did you come to be the leader of this garden?

2. Is being the leader of the garden a paid position?

3. Who is involved with the decision making for the garden?

- How are group decisions made?

4. What skills do you have that you bring to the garden?

5. What services do you provide for the garden?

- What else does your position entail?

6. Do you help provide them with gardening knowledge?

- Do you see participants using local knowledge for their gardening and sharing that knowledge with other participants?

7. Do you provide seeds and gardening supplies for the members?

8. How often do you visit the garden?

- For what reasons do you visit?

9. Do you help garden in the garden?

- What are your main motivations for producing the food?

10. Do you have regular conversations with the members of the garden?

11. How many active members did you have in 2016 ?

- Last summer did the garden have high or low demand for members/volunteers? Why high or why low?

12. What do you think the main motivation is for those who garden at your garden?

13. What makes a good garden member/volunteer?

14. What do you think are the characteristics of a successful garden?

15. Have you had any issues with getting access to or having control over your land, water, or seeds for the garden?

\section{For Contract Gardens}

16. Do you believe the gardening contract is helpful for the garden vs. not having a contract? Why or why not?

\section{For Gardens that have a Fee}

17. Is having a fee useful for the garden?

- What is the money from the fees used for?

- Is the fee used to cover garden costs? What are these costs? Is the fee sufficient enough to cover the costs?

- Do you know of any instances where someone could not join because of the fees?

- Do you reduce or waive fees for people who cannot afford it?

18. Do you see yourself as being a part of a movement? If yes, a movement for what?

19. What are your goals for the garden and your main vision for it?

- Do you think the other members of the garden agree with this vision?

20. Is the garden trying to provide food for people who did not have access to healthy food 
before? Why?

- Trying to provide food for people who cannot afford healthy food? Why?

- Trying to promote community development? Why?

- Trying to promote healthy eating? Why?

- Trying to engage children in food production and healthy eating? Why?

- Trying to educate people about food and growing food? Why?

- Trying to promote local food production? Why?

- Trying to provide organic, chemical free food? Why?

- Trying to provide a more sustainable way to produce food? Why?

- Trying to let people be more self-sufficient? Why?

- Trying to provide more control over the production of the food? Why?

21. Do you see the food from the garden as being better than food from supermarkets? Why or why not?

22. Do you see what you do as political?

23. Are you trying to provide a space where gardeners can exercise certain rights that you believe they should have? If yes, what rights and why? 